\title{
DISTRIBUTION AND POTENTIAL RISK OF METALS AND METALLOIDS IN SOIL OF INFORMAL E-WASTE RECYCLING SITES IN LAGOS, NIGERIA
}

\author{
Adeyi, A. A. ${ }^{12^{* *}}$, Olayanju, B. ${ }^{1}$ and Fatade, Y. ${ }^{1}$ \\ ${ }^{1}$ Department of Chemistry, University of Ibadan, Ibadan, Nigeria \\ ${ }^{2}$ Geo-Environmental Research Centre Laboratory, Basel Convention Coordinating Centre for Training and Technology \\ Transfer for Africa Region, University of Ibadan, Ibadan, Oyo State, Nigeria. \\ "Corresponding Author E-mail Address: bolaoketola@yahoo.com; Tel. No: +234 8037763961 \\ (Received: 26th July, 2019; Accepted: 5th November, 2019)
}

\section{ABSTRACT}

Crude and haphazard informal e-waste recycling has resulted in environmental pollution with detrimental effects on human health. The present study assesses the levels of metals and metalloids ( $\mathrm{Pb}, \mathrm{Mn}, \mathrm{Fe}, \mathrm{Zn}, \mathrm{Co}, \mathrm{Cd}$, $\mathrm{Ni}, \mathrm{Ag}, \mathrm{Cu}, \mathrm{As}, \mathrm{Ba}, \mathrm{Cr}, \mathrm{Ca}, \mathrm{Mg}, \mathrm{K}$, and $\mathrm{Na}$ ) in topsoil of informal e-waste recycling sites in Lagos, Nigeria. Topsoil samples $(0-15 \mathrm{~cm})$ were randomly collected at different informal e-waste recycling hubs in Lagos. Samples were digested and the levels of heavy metals and metalloids were determined using ICP-OES. Soil contamination indices, ecological and human health risks were evaluated using contamination factor, degree of contamination, geo-accumulation index, ecological risk index (RI), and human risk index (HI), respectively. There were variations in the concentrations of metals and metalloids in the soil, which ranged from 7.05-16,350 $\mathrm{mg} / \mathrm{kg} \mathrm{Pb}, 14.4-3,373 \mathrm{mg} / \mathrm{kg} \mathrm{Cu}, \mathrm{ND}-21.9 \mathrm{mg} / \mathrm{kg} \mathrm{Cd}$, and ND-166 mg/kg Ni. Lead had the highest mean concentration of $7394 \pm 7759 \mathrm{mg} / \mathrm{kg}$ in soil around the dismantling points at Ojota scrap market. Ojota scrap market also had the highest concentrations of all the metals except Co, Cd, As and Ba. Health risk index (HI) ranged from 3.93-183 in both children and adults populations. These calls for concern due to potential health risk associated with human exposure to toxic metals, some of which are also endocrine disruptors. There is need for proper management of e-waste in Nigeria to prevent human exposure to these toxic substances present therein.

Keywords: Electronic waste, environmental contamination, heavy metals, recycling, health risk, waste management

\section{INTRODUCTION}

Inventory and volume of outdated electronic equipment is constantly growing due to rapid innovation and technological advancement. These outdated equipment are eventually disposed of as electronic waste or e-waste (SOT, 2013). E-waste are discarded appliances that has or could enter the waste stream such as waste electronic goods (e.g., computers, televisions and mobile phones), which uses electricity before it reached its end-oflife and then becomes waste stream; and traditionally non-electronic goods such as refrigerators, ovens, washing machines, dryers, etc., home entertainment and stereo systems, toys, toasters, kettles and almost any household or business item with circuitry or electrical components with power or a battery supply (Robinson, 2009; Pérez-Belis et al., 2015). E-waste contains valuable metals such as $\mathrm{Cu}$ and platinum group elements that can be extracted as well as more than one thousand toxic substances including potential environmental contaminants such as $\mathrm{Pb}, \mathrm{Cd}$, $\mathrm{Ni}$, etc., brominated flame retardants such as polybrominated diphenyl ethers (PBDEs), and polychlorinated biphenyls (PCBs) (Puckett and Smith, 2002; Araújo et al., 2012; Kiddee et al., 2013). The presence of halogenated compounds in e-wastes have been reported to results in the release of toxic, bio-accumulative and persistent organic pollutants such as dioxins and furans during recycling processes, which can jeopardize public health (Chakraborty et al., 2018). Burning e-waste may generate dioxins, furans, polycyclic aromatic hydrocarbons (PAHs), polyhalogenated aromatic hydrocarbons (PHAHs), and hydrogen chloride (Robinson, 2009; Steiner, 2004; Leung et al., 2006; Williams et al., 2008; Li et al., 2011; Luo et al., 2011; A tiemo et al., 2012; Amfo-Out et al., 2013; Song and Li, 2014; Tsydenova and Bengtsson, 2011). Some of these substances have also been reported to be endocrine disruptors due to their ability to mimic or antagonize the action of endogenous hormones, interfere with the synthesis, transport, metabolism, and excretion of natural hormones; and also alter the hormone receptor levels causing 
adverse effects in both humans and animals including aquatic organisms and wildlife (EC, 1999; Baker, 2001; Sheikh et al., 2017).

The growth of informal e-waste recycling sector in many developing countries including Nigeria has created an emerging environmental problems due to the non-stringent environmental laws and very weak enforcement (Bridgen et al., 2005; Chakraborty et al., 2018). E-waste recycling is a rapidly growing business globally and a major pollution sources with associated environmental and human health problems (Kaya and Sözeri, 2009). Though, it can recover materials and other reusable components such as $\mathrm{Cu}$ and precious metals, however, it has resulted in environmental contamination with adverse effects on humans and animals. Due to high costs of labour, lack of facilities and stringent environmental laws and regulations, developed countries do not recycle ewastes (Robinson, 2009; Perkins et al., 2014). These wastes are either landfilled or exported to developing countries as second hand electronic goods while the unserviceable and unrepairable ones are recycled. Developing countries lack the facilities and technical know-how to handle this category of waste. Thus, resulting in crude and haphazard recycling which resulted in contamination of environmental media and human health issues (Echegaray and Hansstein, 2016; Caravanos et al., 2011; Araújo et al., 2012).

Studies have shown a direct impact of crude and backyard recycling of e-waste on workers in Nigeria (Igharo et al., 2014; Igharo et al, 2015a, 2015b; Igharo et al., 2016); Ghana (Nukpezah et al., 2014; Asante et al., 2012; Caravanos et al., 2011); China (Chan et al., 2007; Zhao et al., 2008; Huo et al., 2008; Huo et al., 2007; Wang et al., 2009; Zheng et al., 2008); and India (Steiner, ,2004; Ha et al., 2009; Eguchi et al., 2012). Also, on plant (roots of onion bulbs) (Bakare et al., 2012; Bakare et al., 2013; Olafisoye et al., 2013). The danger posed by toxic substances in e-waste on human health has become a serious societal problem in recent time.

Generally, e-waste refurbishment, collection and recycling takes place in business clusters in Lagos such as Alaba International Market and Ikeja Computer village, which are involved in refurbishment, repairs and marketing of used electrical and electronic goods. Westminster and Lawanson Markets are also hubs for second-hand equipment (Manhart et al., 2011). Collection, dismantling, sorting and recycling of e-waste takes place at Ojota scrap market. This study therefore assesses the levels of metals and metalloids in topsoil of e-waste recycling hubs in Lagos, Nigeria where e-waste collection, recycling, refurbishing, repairs, dismantling and open burning were the major recycling processes. Soil contamination, ecological and human health risks were evaluated using contamination factor, degree of contamination, geo-accumulation index, ecological risk index, and human risk index (HI). Soil characteristics were also determined.

\section{MATERIALS AND METHODS Description of the study areas}

Four major e-waste recycling hubs in Lagos were selected for this study. Alaba International Market is the largest market of used and new electrical and electronic goods in Africa. Ikeja Computer Village Market is active in the sales of second-hand products. Westminster Electronic Market is situated in Apapa Local Government Area of Lagos. Storing used electrical and electronics equipment before being redistributed to other markets or exported to neighbouring countries takes place therein (Adaramodu et al., 2012; Manhart et al., 2011). Ojota scrap market is known for the dismantling and sorting of solid wastes including electrical and electronics equipment (Figure 1). 


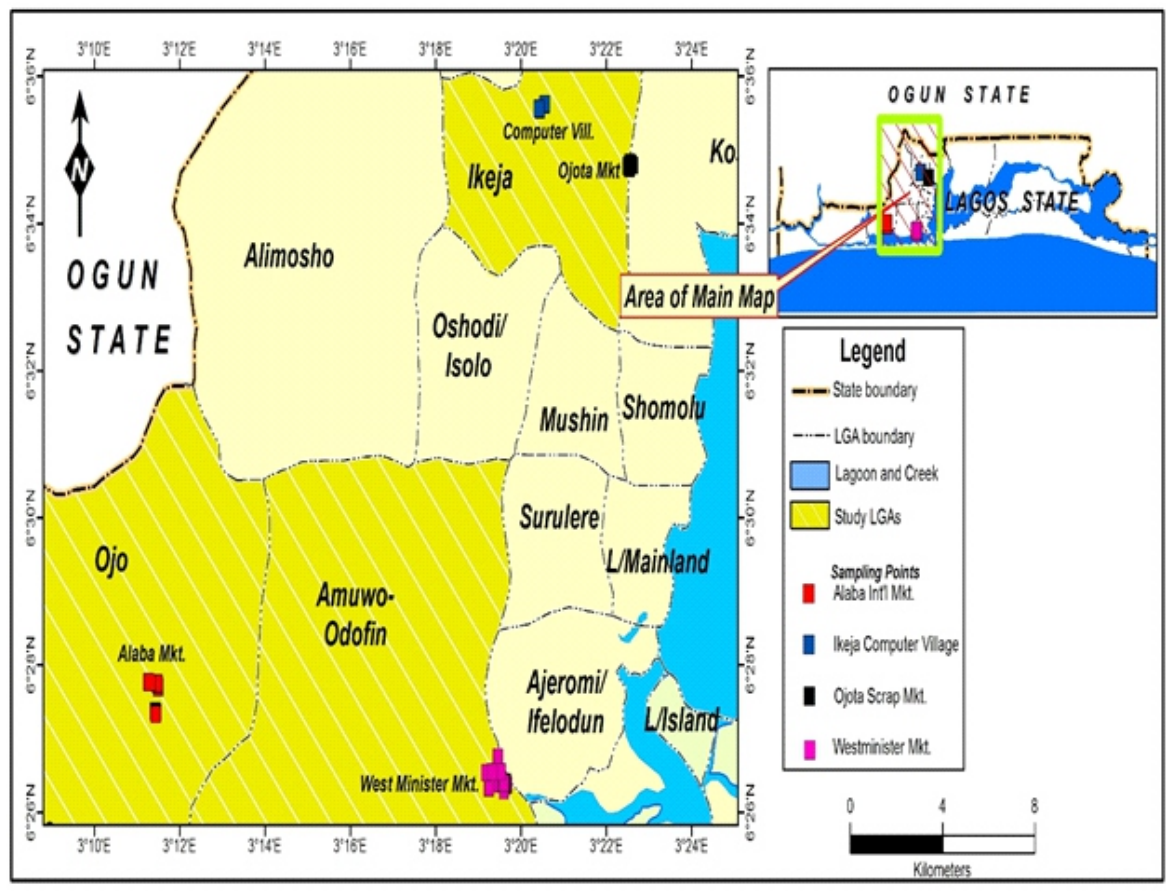

Figure 1: Map of Lagos showing the sampling locations

\section{Sample collection and Treatment}

Topsoil $(0-15 \mathrm{~cm})$ including sweeping were collected randomly at ten different locations and mixed together to form a composite at the selected e-waste recycling hubs in Lagos. Control soil sample was collected at the Botanical Garden, University of Ibadan, Ibadan. Since the study locations were all in Lagos and it was assumed that Lagos is more polluted than Ibadan due to anthropogenic activities going on all around Lagos, this informed the choice of Botanical Garden, University of Ibadan as the control site. Ten soil samples were collected at different points and mixed together to form a composite at that location in Alaba International market, Ojota scrap market and Westminster market. A total of 60 soil samples each were collected at Alaba International market, Ojota scrap market and Westminster market and composited. At Ikeja Computer Village, samples were collected at 5 different points and mixed together to form a composite at that location. A total of 30 samples were collected and composited. Samples were prepared in the laboratory by air drying, then pulverized and sieved using $2 \mathrm{~mm}$ sieve.

\section{Sample analysis}

The concentrations of toxic metals in the samples were determined using Inductively Coupled
Plasma-Atomic Emission Spectrometry (ICPAES, Perkin Elmer Optima 8000) after acid digestion of about $2 \mathrm{~g}$ of the dried and sieved soil samples using $20 \mathrm{~mL}$ of $2 \mathrm{M} \mathrm{HNO}_{3}$. The resulting digestates were made up to mark using $0.1 \mathrm{~mL}$ $\mathrm{HNO}_{3}$. Reagent blank and control samples were also digested (USEPA, 2007). Soil physicochemical characteristics were determined using standard analytical procedures (Walkey and Black, 1934)

Soil contamination, ecological risk and human health risk assessment

\section{Quantification of Soil Contamination}

Soil contamination was assessed using contamination factor, degree of contamination, geo-accumulation index, and ecological risk index.

\section{Contamination factor (CF) and degree of contamination (DC)}

The contamination factor and degree of contamination were used to evaluate the soil contamination (Adeyi and Torto, 2014). CF was defined according to four categories as follows: $\mathrm{C}_{\mathrm{f}}^{\mathrm{i}}<1$ low contamination; $1 \leq \mathrm{C}_{\mathrm{f}}^{\mathrm{i}}<3$ moderate contamination; $3 \leq \mathrm{C}_{\mathrm{f}}^{\mathrm{i}}<6$ considerable contamination; $6 \leq \mathrm{C}_{\mathrm{f}}^{\mathrm{i}}$ very high contamination. Contamination factor $(\mathrm{CF})$ was calculated using 
the expression

$\mathrm{CF}=\mathrm{Ci} / \mathrm{Cn}$

The overall degree of contamination (DC) defines the quality of the environment and is expressed as:

$\mathrm{DC}=\sum_{i=1}^{n} C F$

Where; $\mathrm{CF}=$ contamination factor; $\mathrm{Ci}=$ mean concentration of each metal in the soil; $C_{n}=$ baseline or background value (concentration of each metal in the control sample was used); $\mathrm{n}=$ number of analysed elements; $i=$ ith element (or pollutants). Modified formula of CF was used as reported by Adeyi and Torto (2014).

\section{Geo-accumulation Index $\left(\mathrm{I}_{\text {geo }}\right)$}

Geo-accumulation index shows the degree of anthropogenic pollution in the soil samples (Chai et al. 2014). It is expressed as

$$
\text { Igeo }=\log _{2}(\mathrm{Cn} / 1.5 \mathrm{Bn})
$$

Where; $\mathrm{Cn}$ is the measured concentration of heavy metals; $\mathrm{Bn}$ is the geochemical background value in average shale of element $\mathrm{n}$ (Habes and Nigem, 2006) and 1.5 is the background matrix correction factor due to lithogenic effects. The geo-accumulation index $\left(\mathrm{I}_{\text {geo }}\right)$ of metals and their corresponding contamination strength was expressed in line with Forstner et al., 1993: <0, unpolluted; 0-1, unpolluted to moderately polluted; 1-2, moderately polluted; 2-3, moderately polluted to highly polluted; $3-4$, highly polluted, 4-5, highly polluted to very highly polluted; $>5$, very highly polluted.

\section{Potential Ecological Risk Index (RI)}

The potential ecological risk index (RI) assess the level of metal pollution based on the toxicity of the metal and was able to evaluate the ecological risk caused by the toxic metals. The RI was calculated using the expression (Haciyakupoglu et al., 2014):

$$
\begin{aligned}
& F i=C s / C r \\
& \text { Eir }- \text { Tir } x F i \\
& R I=\sum_{i=1}^{n} E i r
\end{aligned}
$$

Where; Fi is the single metal pollution index; Cs is the concentration of metal in the samples; $\mathrm{Cr}$ is the reference value for the metal; Eir is the monomial potential ecological risk factor; Tir is the metal toxic response factor according to Hakanson (1980), $\mathrm{Zn}=1<\mathrm{Cr}=2<\mathrm{Cu}=\mathrm{Ni}=\mathrm{Pb}$ $=5<\mathrm{As}=10<\mathrm{Cd} 30<\mathrm{Hg} 40 . \mathrm{RI}$ is the potential ecological risk caused by the overall contamination categorized in the four classes as shown in Table 1. In this study, a simplified approach to risk assessment was used as reported by Adeyi and Torto (2014).

Table 1: Potential ecological risk factor and risk indices

\begin{tabular}{|l|l|l|l|}
\hline Ei value & $\begin{array}{l}\text { Level of ecological } \\
\text { risk of metal }\end{array}$ & RI value & $\begin{array}{l}\text { Ecological risk }(\mathrm{RI}) \\
\text { category }\end{array}$ \\
\hline $\mathrm{Ei}<40$ & Low risk & $\mathrm{RI}<110$ & Low risk \\
\hline $40 \leq \mathrm{Ei}<80$ & Moderate risk & $110 \leq \mathrm{RI}<200$ & Moderate risk \\
\hline $80 \leq \mathrm{Ei}<160$ & Considerable risk & $200 \leq \mathrm{RI}<400$ & Considerable risk \\
\hline $160 \leq \mathrm{Ei}<320$ & High risk & $200 \leq \mathrm{RI}<400$ & Very high risk \\
\hline $320 \leq \mathrm{Ei}$ & Very high risk & $400 \leq \mathrm{RI}$ & \\
\hline
\end{tabular}

\section{Human health risk assessment}

Human beings are exposed to toxic chemicals via inhalation, ingestion and dermal contact. To assess the potential health effects of heavy metals and metalloids on the people around the e-waste recycling sites in Lagos, the following were estimated:

\section{Daily intake via ingestion}

The daily dose intake ([D(ing)] in $\mathrm{mg} / \mathrm{kg} /$ day) of heavy metals and metalloids from soil and dust of the sites on infants and children through ingestion was determined using the expression:

$\mathrm{D}_{\text {(ing) }}=\mathrm{C}(\mathrm{mg} / \mathrm{kg}) \times \underline{\operatorname{IngR} \times \mathrm{EF} \times \mathrm{ED}} \times 10^{-6}$ 
Where; $\mathrm{C}$ is the concentration of the elements in the sample, IngR is the ingestion rate ( $\mathrm{mg} /$ day), $\mathrm{EF}$ is the exposure frequency $(\mathrm{d} / \mathrm{y}), \mathrm{ED}$ is the exposure duration (years), BW the body weight $(\mathrm{kg})$ and AT is the averaging time (days) (Table 2).

\section{Daily intake via dermal contact}

$$
\mathrm{D}_{(\mathrm{derm})}=\mathrm{C}(\mathrm{mg} / \mathrm{kg}) \times \frac{\mathrm{SA} \times \mathrm{SL} \times \mathrm{ABS} \times \mathrm{EF} \times \mathrm{ED}}{\mathrm{BW} \times \mathrm{AT}} \times 10^{-6}
$$

\section{Daily intake via inhalation$$
\mathrm{D}_{(\text {(nh) }}=\mathrm{C}(\mathrm{mg} / \mathrm{kg}) \times \frac{\mathrm{InR} \times \mathrm{PEF} \times \mathrm{EF} \times \mathrm{ED}}{\mathrm{BW} \times \mathrm{AT}} \times 10^{-6}
$$

Where; $\mathrm{C}$ is the concentration of the elements in the sample, IngR is the ingestion rate, $\operatorname{InR}$ is the inhalation rate, $\mathrm{SA}$ is the exposure surface area $\left(\mathrm{cm}^{2} /\right.$ day $)$, SL is the skin adherence factor $\left(\mathrm{mg} / \mathrm{cm}^{2} /\right.$ day), ABS is the skin absorption factor, $\mathrm{EF}$ is the exposure frequency $(\mathrm{d} / \mathrm{y}), \mathrm{ED}$ is the exposure duration (years), PEF is the particulate emission factor, BW is the body weight ( $\mathrm{kg}$ ) and
AT is the averaging time (days) (Table 2).

The risk of exposure to a particular toxicant (cancer risk) was calculated using the expression Risk $=\mathrm{DI} \times \mathrm{SF}$

The risk of exposure to a particular toxicant (noncancer risk) is the Hazard Quotient

(HQ) and is given by:

$\mathrm{HQ}=\underline{\mathrm{DI}}$

RfD

Where; Risk is a unitless probability of an individual developing cancer over a lifetime; SF is the slope factor, expressed in $(\mathrm{mg} / \mathrm{kg} /$ day $)$; DI is the daily intake by a given route of exposure; RfD is the reference dose (Table 3) (Atiemo et al., 2012; Adaramodu et al., 2012). It was assumed that heavy metals and metalloids have toxic additive effects, therefore the HQ values of each metal were summed together to generate the Hazard Index (HI) (Leung et al., 2008).

Table 2: Exposure parameters used for the estimation of health risk through different pathways

\begin{tabular}{llll}
\hline Parameters & Unit & Children & Adults \\
\hline Body weight (BW) & $\mathrm{kg}$ & 15 & 70 \\
Exposure frequency (EF) & days/year & 350 & 350 \\
Exposure duration (ED) & years & 6 & 30 \\
Ingestion rate (IR) & $\mathrm{mg} /$ day & 200 & 100 \\
Inhalation rate (IN) & $\mathrm{m}^{3} /$ day & 10 & 20 \\
Skin surface area (SA) & $\mathrm{cm}^{2}$ & 2100 & 5800 \\
Soil adherence factor (AF) & $\mathrm{mg} / \mathrm{cm}^{2}$ & 0.2 & 0.07 \\
Dermal Absorption factor (ABS) & none & 0.1 & 0.1 \\
Dermal exposure ratio (FE) & none & 0.61 & 0.61 \\
Particulate emission factor (PEF) & $\mathrm{m}^{3} / \mathrm{kg}$ & $1.3 \times 10^{9}$ & $1.3 \times 10^{9}$ \\
Conversion factor (CF) & $\mathrm{kg} / \mathrm{mg}$ & $10^{-6}$ & $10^{-6}$ \\
Average time (AT) & days & & $365 \times 70$ \\
\multicolumn{1}{c}{ For carcinogens } & & $365 \times \mathrm{ED}$ & $365 \times \mathrm{ED}$ \\
\multicolumn{1}{c}{ For non-carcinogens } & & & \\
\hline
\end{tabular}

(DEA, 2010)

Hazardous emission during burning of ewaste

E-wastes contains several heavy metals which are likely to be released during burning. Cadmium is emitted majorly during burning of printed wiring boards (PWBs) while $\mathrm{Pb}$ is released during burning of PWBs and capacitors. The tolerable daily intake (TD) of $\mathrm{Cd}$ is $7 \mathrm{ug} / \mathrm{kg}$ while $\mathrm{Pb}$ is 3.5 ug/kg (Steiner, 2004; WHO, 1987). Hazardous emission of $\mathrm{Cd}$ and $\mathrm{Pb}$ during e-waste burning were calculated using the expression:

No Risk: $\underline{\mathrm{DI}}<1$ and Risk: $\underline{\mathrm{DI}}>1$

$$
\text { TDI TDI }
$$

The TDI is the daily intake, which should not lead to any chronic health impacts if the given amount is consumed daily during the whole life. 
Table 3: Reference doses (RfD) in (mg/kg-day) and Cancer Slope Factors (CSF) for the different heavy metals

\begin{tabular}{lllllll}
\hline \multicolumn{2}{l}{ Heavy metals Oral } & Dermal & Inhalation & \multicolumn{2}{l}{ Oral CSF } & \multicolumn{2}{l}{ Dermal CSF Inhalation CSF } \\
\hline $\mathrm{As}^{\mathrm{a}}$ & $3.00 \mathrm{E}-04$ & $3.00 \mathrm{E}-04$ & $3.00 \mathrm{E}-04$ & $1.50 \mathrm{E}+00$ & $1.50 \mathrm{E}+00$ & $1.50 \mathrm{E}+01$ \\
$\mathrm{~Pb}^{\mathrm{a}}$ & $3.60 \mathrm{E}-03$ & - & - & $8.50 \mathrm{E}-03$ & - & $4.20 \mathrm{E}-02$ \\
$\mathrm{Cd}^{a}$ & $5.00 \mathrm{E}-04$ & $5.00 \mathrm{E}-04$ & $5.70 \mathrm{E}-05$ & - & - & $6.30 \mathrm{E}+00$ \\
$\mathrm{Cr}^{\mathrm{a}}$ & $3.00 \mathrm{E}-03$ & - & $3.00 \mathrm{E}-05$ & $5.00 \mathrm{E}-01$ & - & $4.10 \mathrm{E}+01$ \\
$\mathrm{Co}^{\mathrm{b}}$ & $2.00 \mathrm{E}-02$ & $5.70 \mathrm{E}-06$ & $5.70 \mathrm{E}-06$ & - & - & $9.80 \mathrm{E}+00$ \\
$\mathrm{Ni}^{\mathrm{a}}$ & $2.00 \mathrm{E}-02$ & $5.60 \mathrm{E}-03$ & - & - & - & - \\
$\mathrm{Cu}^{a}$ & $3.70 \mathrm{E}-02$ & $2.40 \mathrm{E}-02$ & - & - & - & - \\
$\mathrm{Zn}^{a}$ & $3.00 \mathrm{E}-01$ & $7.50 \mathrm{E}-02$ & - & - & - & - \\
\hline
\end{tabular}

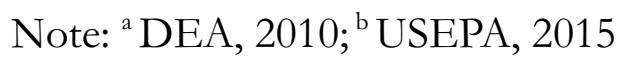

\section{RESULTS AND DISCUSSION Soil characteristics}

The $\mathrm{pH}$ of topsoil of e-waste recycling sites in Lagos ranged from 6.9-9.2. The descriptive statistics of the soil physico-chemical characteristics is presented in Table 4. Soil samples collected at Alaba international market (burning points) had the highest $\mathrm{pH}$ while the lowest $\mathrm{pH}$ was obtained at dismantling and burning points, respectively at Ojota scrap yard. The mean concentration of soil $\mathrm{pH}$ at Alaba international market (burning and dismantling), Computer village (dismantling and dismantling with traces of burning), Westminster market (repair and dumping) and Ojota scrap yard (dismantling and burning) were $8.43 \pm 0.7$ and $8.17 \pm 0.3 ; 7.70 \pm 0.4$ and $7.93 \pm 0.5 ; 8.01 \pm 0.1$ and $8.07 \pm 0.5$; and $7.10 \pm 0.2$ and $7.37 \pm 0.4$, respectively while it was $6.6 \pm 0.1$ in the control soil. The $\mathrm{pH}$ of soil samples collected at the burning points in all the selected ewaste recycling hubs were higher than what was obtained in other recycling activity points such as dumping and dismantling. Soil $\mathrm{pH}$ has been shown to correlate with the availability of nutrients to plant and also affects the mobility of heavy metals. (Gray et al., 1998; Amos-Tautua et al., 2014). Consequently, as $\mathrm{pH}$ decreases, the solubility and availability of metallic elements in soil increases (Oliver et al., 1998). Also, the optimal $\mathrm{pH}$ range for most plants is between 5.5 and 7.0. The values obtained in all the sites were higher than the optimal $\mathrm{pH}$ range for plant growth.

The soil organic matter ranged from 1.11-10.7 \% at the burning and dismantling points at Ojota scrap yard. The mean concentrations of soil organic matter (\%) at Alaba international market (burning and dismantling), Computer village (dismantling and dismantling with traces of burning), Westminster market (repair and dumping) and Ojota scrap yard (dismantling and burning) were $4.96 \pm 0.8 \%$ and $4.88 \pm 1.9 \%$; $4.11 \pm 2.2 \%$ and $4.11 \pm 2.2 \% ; 4.05 \pm 1.2 \%$ and $4.60 \pm 2.5 \%$; and $7.78 \pm 3.2 \%$ and $5.84 \pm 4.1 \%$, respectively while it was $3.75 \pm 1.3 \%$ in the control soil. Usually, most productive agricultural soils have organic matter between 3-6\%. These contributes to soil productivity, binds soil particles into aggregates and improves water holding capacity of soil. Native top soil contains about $5 \%$ organic matter by weight (10\% by volume). More than this will start causing problems for plants by providing nutrient levels that are too high (Bot and Benites, 2005). The soil organic matter in all the soils collected at the informal e-waste recycling sites in Lagos were within the values for productive soil except the soil collected at Ojota scrap yard. Increase in soil organic matter leads to an increase in $\mathrm{pH}$ in acidic soils

The soil samples collected at the informal recycling sites in Lagos were dominated by coarse particles of sand with the mean values which ranged from $88.5 \pm 1.3-97.4 \pm 0.6 \%$ at the Ikeja Computer Village and Alaba International Markets dismantling points, respectively. Generally, the percentage of sand in the soil was high. The high percentage of sand may pose the risk of pollutants leaching from the topsoil to the subsoil. The mean value of clay ranged from $0.07 \pm 0.1-7.83 \pm 1.5 \%$ at the Ojota scrap yard burning points and Computer Village, Ikeja dismantling points, respectively. When compared with the control soil samples, the mean value of sand in the soils collected at the informal recycling 
sites were higher than what was obtained in the control sample $(89.8 \pm 1.4 \%)$ except Computer Village, Ikeja dismantling points $(88.5 \pm 1.3 \%)$. The mean value of clay in the control samples $(2.8 \pm 0.0 \%)$ was higher than the values obtained in the soils collected at all the informal recycling sites in Lagos except Computer Village, Ikeja dismantling points $(7.83 \pm 1.5 \%)$ and dismantling points with traces of burning $(5.33 \pm 0.8 \%)$, also at Computer Village in Ikeja. The soil particle distribution obtained at the recycling sites might be attributed to the different recycling activities going on at the sites.

Table 4: Soil characteristics of informal e-waste recycling sites in Lagos, Nigeria

\begin{tabular}{|c|c|c|c|c|c|c|}
\hline \multirow[t]{2}{*}{$\mathrm{S} / \mathrm{N}$} & \multirow{2}{*}{$\begin{array}{l}\text { E- waste management } \\
\text { sites/sample codes }\end{array}$} & \multirow[t]{2}{*}{$\mathrm{pH}$} & \multicolumn{3}{|c|}{ Particle Size Distribution (\%) } & \multirow{2}{*}{$\begin{array}{l}\text { Soil Organic } \\
\text { Matter }(\%)\end{array}$} \\
\hline & & & Sand & Silt & Clay & \\
\hline \multirow[t]{11}{*}{1.} & Alaba Intl' Market & & & & & \\
\hline & Burning points & & & & & \\
\hline & AIMB1 & 8.1 & 96.6 & 2.3 & 1.1 & 5.22 \\
\hline & AIMB2 & 8.0 & 96.1 & 2.0 & 1.9 & 5.60 \\
\hline & AIMB3 & 9.2 & 87.6 & 10.3 & 2.1 & 4.07 \\
\hline & Mean \pm SD & $8.43 \pm 0.7$ & $93.4 \pm 5.1$ & $4.87 \pm 4.7$ & $1.70 \pm 0.5$ & $4.96 \pm 0.8$ \\
\hline & Dismantling points & & & & & \\
\hline & AIMD4 & 7.9 & 97.1 & 1.0 & 1.9 & 6.88 \\
\hline & AIMD5 & 8.2 & 96.9 & 1.0 & 2.1 & 4.71 \\
\hline & AIMD6 & 8.4 & 98.1 & 0.5 & 1.4 & 3.05 \\
\hline & Mean \pm SD & $8.17 \pm 0.3$ & $97.4 \pm 0.6$ & $0.83 \pm 0.3$ & $1.8 \pm 0.4$ & $4.88 \pm 1.9$ \\
\hline \multirow[t]{11}{*}{2.} & Computer village, Ikeja & & & & & \\
\hline & Dismantling points & & & & & \\
\hline & ICVD1 & 7.8 & 88.0 & 4.7 & 7.3 & 1.64 \\
\hline & ICVD2 & 7.3 & 90.0 & 3.3 & 6.7 & 5.75 \\
\hline & ICVD3 & 8.0 & 87.5 & 3.0 & 9.5 & 4.93 \\
\hline & Mean \pm SD & $7.70 \pm 0.4$ & $88.5 \pm 1.3$ & $3.67 \pm 0.9$ & $7.83 \pm 1.5$ & $4.11 \pm 2.2$ \\
\hline & $\begin{array}{l}\text { Dismantling points with traces of } \\
\text { burning }\end{array}$ & & & & & \\
\hline & ICVDB4 & 7.4 & 93.0 & 1.5 & 5.5 & 5.59 \\
\hline & ICVDB5 & 8.4 & 92.5 & 1.5 & 6.0 & 5.09 \\
\hline & ICVDB6 & 8.0 & 95.0 & 0.5 & 4.5 & 1.64 \\
\hline & Mean \pm SD & $7.93 \pm 0.5$ & $93.5 \pm 1.3$ & $1.17 \pm 0.6$ & $5.33 \pm 0.8$ & $4.11 \pm 2.2$ \\
\hline \multirow[t]{11}{*}{3.} & Westminster market & & & & & \\
\hline & Repair points & & & & & \\
\hline & WMR1 & 8.0 & 95.0 & 3.5 & 1.5 & 3.29 \\
\hline & WMR2 & 7.9 & 95.0 & 3.5 & 1.5 & 3.45 \\
\hline & WMRS3 & 8.1 & 96.0 & 3.0 & 1.0 & 5.41 \\
\hline & Mean \pm SD & $8.0 \pm 0.1$ & $95.3 \pm 0.6$ & $3.33 \pm 0.3$ & $1.33 \pm 0.3$ & $4.05 \pm 1.2$ \\
\hline & Dumping points & & & & & \\
\hline & WMD4 & 7.7 & 93.5 & 4.0 & 2.5 & 6.57 \\
\hline & WMD5 & 8.6 & 94.5 & 4.0 & 1.5 & 1.81 \\
\hline & WMD6 & 7.9 & 94.5 & 4.0 & 1.5 & 5.42 \\
\hline & Mean \pm SD & $8.07 \pm 0.5$ & $94.2 \pm 0.6$ & $4.00 \pm 00$ & $1.83 \pm 0.6$ & $4.60 \pm 2.5$ \\
\hline \multirow[t]{11}{*}{4.} & Ojota scrap market & & & & & \\
\hline & Dismantling points & & & & & \\
\hline & OJSD2 & 7.6 & 95.1 & 3.9 & 1.0 & 4.43 \\
\hline & OJSD3 & 6.9 & 96.4 & 2.4 & 1.2 & 8.21 \\
\hline & OJSD1 & 7.6 & 95.1 & 4.2 & 0.7 & 10.7 \\
\hline & Mean \pm SD & $7.37 \pm 0.4$ & $95.5 \pm 0.8$ & $3.50 \pm 1.0$ & $1.0 \pm 0.3$ & $7.78 \pm 3.2$ \\
\hline & Burning points & & & & & \\
\hline & OJSB4 & 7.1 & 96.1 & 3.9 & 0.0 & 8.12 \\
\hline & OJSB5 & 7.3 & 97.1 & 2.9 & 0.0 & 8.30 \\
\hline & OJSB6 & 6.9 & 96.6 & 4.2 & 0.2 & 1.11 \\
\hline & Mean \pm SD & $7.10 \pm 0.2$ & $96.3 \pm 1.0$ & $3.67 \pm 0.7$ & $0.07 \pm 0.1$ & $5.84 \pm 4.1$ \\
\hline 5. & Control & $6.6 \pm 0.1$ & $89.8 \pm 1.4$ & $7.4 \pm 1.4$ & $2.8 \pm 0.0$ & $3.76 \pm 1.3$ \\
\hline
\end{tabular}




\section{Heavy Metals and Metalloids Concentrations in the Soil}

Heavy metals and metalloids are natural components of soil (Kabata-Pendias and Pendias, 2001). Their concentrations can be increased by human activities and thus, become a pollution concern affecting human health and the entire ecosystem. Some trace elements are required for healthy growth of organisms, but concentrations exceeding threshold can be toxic (Wade et al., 2008; Adeyi and Torto, 2014). The results of toxic metals and metalloids ( $\mathrm{Mn}, \mathrm{Fe}, \mathrm{Cr}, \mathrm{Cu}, \mathrm{Zn}, \mathrm{Co}, \mathrm{Cd}$, $\mathrm{Pb}, \mathrm{Ni}, \mathrm{Ag}, \mathrm{As}$, and $\mathrm{Ba})$, and other elements $(\mathrm{Na}$, $\mathrm{Ca}, \mathrm{K}$ and $\mathrm{Mg}$ ) determined in the soil samples are presented in Table 5. Ojota scrap yard is characterised by the dismantling of scrap metals and burning of e-wastes. The Westminster market exclusively deals with repair of used and obsolete electrical and electronic products.

Chromium concentrations in the topsoil ranged from ND-547 mg/ $\mathrm{kg}$ at dismantling points at Alaba International market and Ojota scrap market, respectively. The highest mean concentrations was $209 \pm 293 \mathrm{mg} / \mathrm{kg}$ at the dismantling points at Ojota scrap market. This was followed by $118 \pm 141 \mathrm{mg} / \mathrm{kg}$ at the repair points, and $42.0 \pm 36 \mathrm{mg} / \mathrm{kg}$ at dumping points at Westminster market, respectively. The mean concentrations of $\mathrm{Cr}$ in all the soil samples were higher than what was obtained in the control samples, $2.88 \mathrm{mg} / \mathrm{kg}$. Chromium can be readily absorbed by human body which might leads to health challenges such as irritation of skin, eyes and membrane, while chronic exposure could lead to DNA damage, cancer and permanent eye injury (Jaishankar et al., 2014). Zinc concentrations in soil samples collected at the selected informal ewaste recycling sites in Lagos were very high when compared to what was obtained in the control sample (Table 5). Zinc concentrations ranged from $45.1 \mathrm{mg} / \mathrm{kg}$ at the dismantling point at Alaba International market to $4487 \mathrm{mg} / \mathrm{kg}$ at the dumping point at Westminster market. The highest mean concentrations of $\mathrm{Zn}$ was 2716 $\pm 979 \mathrm{mg} / \mathrm{kg}$ at the burning points at Ojota scrap market. This was followed by $2334 \pm 2013 \mathrm{mg} / \mathrm{kg}$ at the dismantling points at Alaba International market. The high concentrations of $\mathrm{Zn}$ obtained at the sites compared to the control site ( 50.5 $\mathrm{mg} / \mathrm{kg}$ ) could be attributed to the release of $\mathrm{Zn}$ from $\mathrm{Zn}$ containing e-waste components and other materials such as cables, small motors, accumulators, batteries, screen coating and writing devices (Onwughara et al., 2010). Zinc is an essential element which is required by human body for healthy development but can be toxic at very high concentrations (Plum et al., 2010; Singh et al., 2011). However, exposure to zinc dust or fumes can cause a disease known as metal fume fever and its absorption can lead to abdominal pains, electrolyte imbalance, dehydration and vomiting (Udosen, 2000; Adaramodu et al., 2012; Wardhana and Datau, 2014).

The concentrations of cadmium in the topsoil sample collected at all the selected informal ewaste recycling sites ranged from ND in most of the sites to $21.9 \mathrm{mg} / \mathrm{kg}$ at the burning point at Ojota scrap market. In most cases, the concentrations of $\mathrm{Cd}$ in the soils of the informal e-waste recycling sites and the control were below the detection limit except burning points at Alaba International market and Ojota scrap market with mean concentrations of $2.14 \pm 3.7 \mathrm{mg} / \mathrm{kg}$ and $11.7 \pm 10$, respectively. The level of Cd obtained at these sites may be as a result of the blazing of $\mathrm{Cd}$ containing e-waste components such as cathode ray tube screen, rechargeable $\mathrm{Ni}-\mathrm{Cd}$ batteries, printer drum in photocopier, printer inks and tonners, etc. (Subburaman, 2012). Cadmium is carcinogenic and its inhalation in excess could damage the kidney, DNA and lungs (Singh et al., 2011; Jaishankar et al., 2014). High level of cadmium can also cause cognition, deficit in learning, behaviour and neuromotor skills in children (Thatcher et al., 1982; Rahimzadeh et al., 2017). 
Adeyi et al.: Distribution and Potential Risk of Metals and Metalloids in Soil of Informal E-waste Recycling Sites

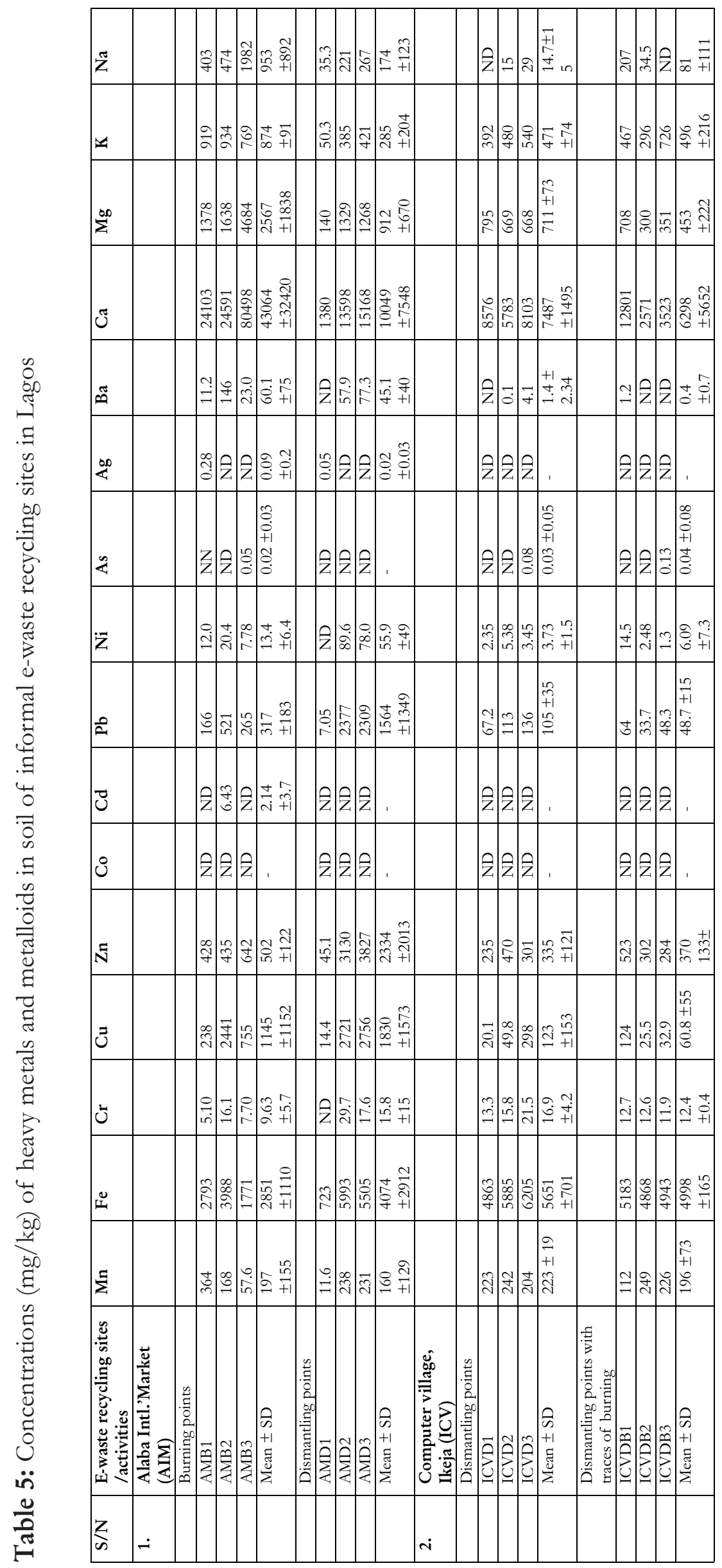


Adeyi et al.: Distribution and Potential Risk of Metals and Metalloids in Soil of Informal E-waste Recycling Sites

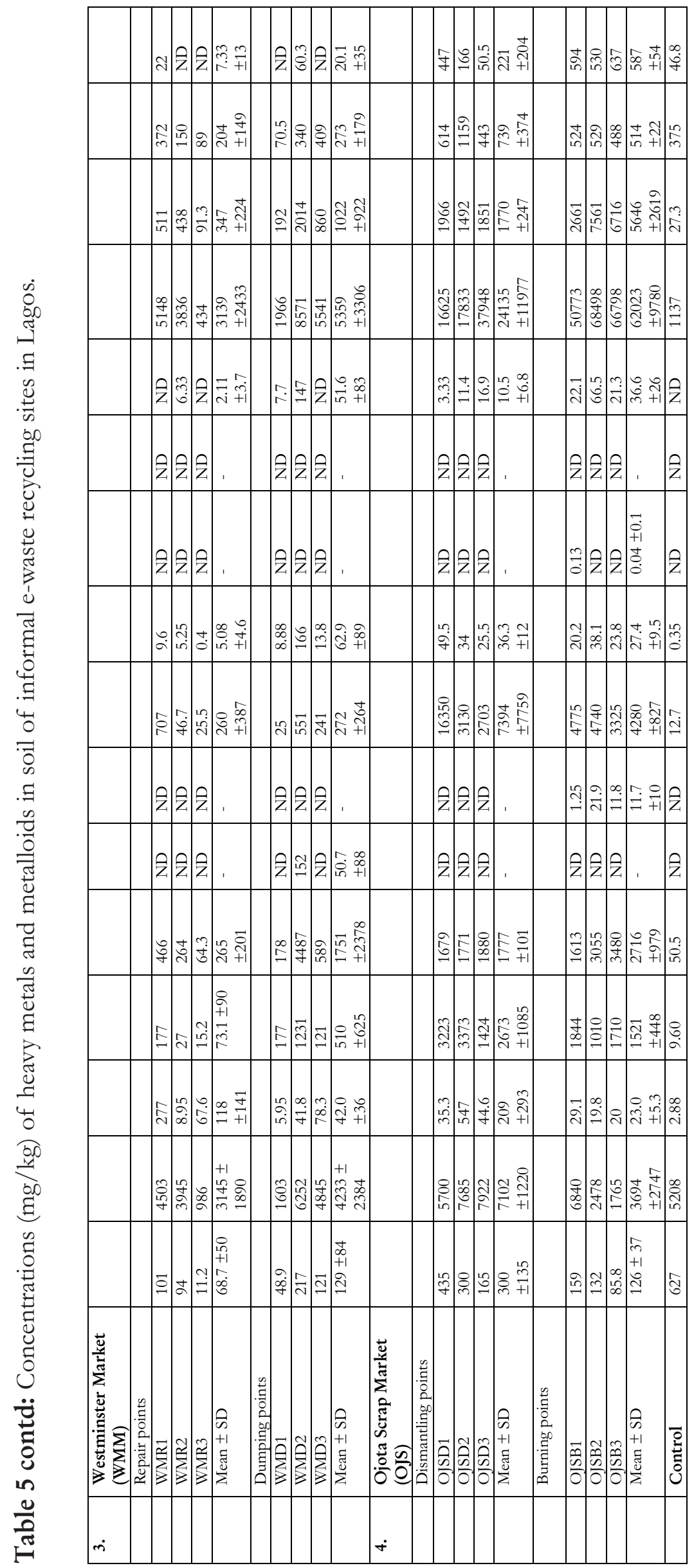


Lead concentrations in the topsoil of informal ewaste recycling sites ranged from $7.05 \mathrm{mg} / \mathrm{kg}$ at the dismantling point at Alaba International market to $16,350 \mathrm{mg} / \mathrm{kg}$ at dismantling point at Ojota scrap market. The highest mean concentrations, $7394 \pm 7759 \mathrm{mg} / \mathrm{kg}$, was obtained at dismantling points at Ojota scrap market, followed by $4280 \pm 827 \mathrm{mg} / \mathrm{kg}$ obtained at the burning points at Ojota scrap market, and 1564 $\pm 1349 \mathrm{mg} / \mathrm{kg}$ obtained at the dismantling points at Alaba International market. When compared with what was obtained in the control sample $(12.7 \mathrm{mg} / \mathrm{kg}$ ) (Table 5), the soil samples collected at the informal e-waste recycling sites in Lagos, in most cases, were over 1,000 times higher than the concentration in the control soil. This may be linked to the burning and dismantling of $\mathrm{Pb}$ containing e-waste components such as rechargeable batteries, printed wiring boards and cathode ray tubes (Okorhi et al., 2017) with high levels of $\mathrm{Pb}$. Exposure to $\mathrm{Pb}$ in a short-term could lead to convulsion or coma, vomiting, and diarrhea, while kidney and nervous damage, brain and blood disorder and death could result with long- term exposure (Jaishankar et al., 2014; Fu and Wang, 2011; Adeyi and Babalola, 2017; Okorhi et al., 2017). The order of $\mathrm{Pb}$ concentrations in the topsoil of informal e-waste recycling sites was repair $<$ dumping $<$ burning $<$ dismantling.

Copper concentrations in the topsoil samples collected at the selected informal e-waste recycling sites in Lagos ranged from $14.4--3,373 \mathrm{mg} / \mathrm{kg}$ at the dismantling points at Alaba International market and Ojota scrap market, respectively (Table 5). The highest mean concentration of $\mathrm{Cu}$ was $2673 \pm 1085 \mathrm{mg} / \mathrm{kg}$ obtained at dismantling points at Ojota scrap market, followed by dismantling points at Alaba International market $(1830 \pm 1573 \mathrm{mg} / \mathrm{kg})$, and $1521 \pm 448 \mathrm{mg} / \mathrm{kg}$ at the burning points at Ojota scrap market. The concentrations of copper in all the soil samples collected were higher than the concentration (9.60 $\mathrm{mg} / \mathrm{kg}$ ) obtained in the control sample. The high $\mathrm{Cu}$ content of the soil may be attributed to e-waste recycling activities at the sites. Copper is an essential trace element, the human body contain copper at a level of about 1.4 to $2.1 \mathrm{mg} / \mathrm{kg}$ of the body mass (Bost et al., 2016). Accumulation of copper in human body can cause several ailments and health problems such as vomiting, diarrhea, irritations of eyes, nose and skin, dizziness, headache, damage of the liver and kidney, and can also lead to death (Bost et al., 2016). The order of $\mathrm{Cu}$ concentrations in the topsoil was dismantling $>$ burning $>$ dumping $>$ repair. Nickel concentrations in the topsoil of the selected informal e-waste recycling sites in Lagos ranged from ND at the dismantling point at Alaba International market to $166 \mathrm{mg} / \mathrm{kg}$ at dumping point in Westminster (Table 5). The nickel concentrations in the topsoil samples collected at the control site was $0.35 \mathrm{mg} / \mathrm{kg}$, which was lower than what was obtained in all the recycling sites. Dismantling points at Computer village, Ikeja had the lowest mean concentration of $\mathrm{Ni}, 3.73 \pm 1.5$ $\mathrm{mg} / \mathrm{kg}$ while the highest mean concentration, 62.9 $\pm 89 \mathrm{mg} / \mathrm{kg}$, was obtained in the topsoil collected at the dumping points at Westminster market (Table 5). Nickel concentrations in the topsoil was in the order: dismantling $>$ burning $>$ dumping $>$ repair.

Iron concentrations in the topsoil of informal ewaste recycling sites in Lagos ranged from 723 $\mathrm{mg} / \mathrm{kg}$ at the dismantling point at Alaba International market to $7922 \mathrm{mg} / \mathrm{kg}$ at the dismantling point at Ojota scrap market. The highest mean concentration of $\mathrm{Fe}$ was 7102 $\pm 1220 \mathrm{mg} / \mathrm{kg}$ obtained at dismantling point at Ojota scrap yard (Table 5). This was followed by $5651 \pm 701 \mathrm{mg} / \mathrm{kg}$ at the dismantling points and $4998 \pm 165 \mathrm{mg} / \mathrm{kg}$ at the dismantling points with traces of burning both at Computer village, Ikeja. The lowest mean concentrations of $\mathrm{Fe}, 2851 \pm 1110$ $\mathrm{mg} / \mathrm{kg}$, was obtained at burning points at Alaba International Market. The order of mean concentrations of Fe was dismantling $>$ dumping $>$ burning $>$ repair. The level of $\mathrm{Fe}$ found in this study could be attributed to the metal scraps being continuously dismantled in the study sites.

The mean concentrations of silver in the topsoil samples collected at all the informal e-waste recycling hubs in Lagos and the control sample were below the detection limit of the instrument except $0.09 \pm 0.2 \mathrm{mg} / \mathrm{kg}$ and $0.02 \pm 0.03 \mathrm{mg} / \mathrm{kg}$ obtained at the burning and dismantling points at Alaba International Market. Similarly, cobalt concentration in all the samples collected at the study sites and the control were below the 
detection limit. However, $50.7 \mathrm{mg} / \mathrm{kg}$ was obtained at Westminster market dumpsite. Arsenic concentrations in all the e-waste recycling sites were below the detection limit except 0.02 $\pm 0.030 \mathrm{mg} / \mathrm{kg}$ and $0.04 \pm 0.1 \mathrm{mg} / \mathrm{kg}$ obtained at the burning points at Alaba International Market and Ojota scrap yard, respectively, and $0.04 \pm 0.08$ $\mathrm{mg} / \mathrm{kg}$ at the dismantling points with traces of burning at Computer village, Ikeja. The concentrations of manganese $(\mathrm{Mn})$ in the topsoil samples ranged from $11.2 \mathrm{mg} / \mathrm{kg}$ obtained at Alaba International Market to $435 \mathrm{mg} / \mathrm{kg}$ at Ojota scrap market. The order of Mn concentrations in the topsoil of informal e-waste recycling sites in Lagos was dismantling $>$ burning $>$ dumping $>$ repair.

The concentrations of other elements $(\mathrm{Ca}, \mathrm{Mg}, \mathrm{K}$, and $\mathrm{Na}$ ) in the topsoil of informal e-waste recycling sites in Lagos occurred in decreasing order: $\mathrm{Ca}>\mathrm{Mg}>\mathrm{K}>\mathrm{Na}$. These elements are part of the most common elements in the earth's crust. There were variations in the concentrations of these elements in the topsoil of the informal ewaste recycling sites in Lagos. The order of these metals in the topsoil samples based on the recycling activities were:

Ca: burning $>$ dismantling $>$ dumping $>$ repair Mg: burning $>$ dismantling $>$ dumping $>$ repair $\mathrm{K}$ : dismantling $>$ burning $>$ dumping $>$ repair $\mathrm{Na}$ : burning $>$ dismantling $>$ dumping $>$ repair.

\section{Results of soil contamination indices and risk assessment}

The geo-accumulation index (Igeo) of heavy metals in the top soil are presented in Table 6. Lead had the highest Igeo values at dismantling points at Ojota scrap market (strongly/heavily to extremely contaminated), followed by burning points at the same scrap market (strongly/heavily to extremely contaminated), and dismantling points at Alaba International market (strongly/heavily to extremely contaminated). Copper, $\mathrm{Zn}$, and $\mathrm{Cd}$ also had high Igeo values while all the other elements had values below one which signified that the soil were unpolluted by $\mathrm{Mn}, \mathrm{Fe}, \mathrm{Cr}, \mathrm{Co}, \mathrm{Ni}, \mathrm{As}, \mathrm{Ag}$ and $\mathrm{Ba}$.

Contamination factor (CF) and degree of contamination (DC) values are presented in Table 7. Manganese, Fe, Ni, Cr, As, Ag and Ba have CF below 1, which indicated low contamination. Lead had the highest CF (462) at dismantling points at Ojota scrap market. This was followed by $\mathrm{Cu}$ and $\mathrm{Zn}$ in all the recycling sites. The degree of contamination (DC) ranged from 7.16-516, suggesting very high contamination. This showed that the ecosystem is vulnerable to a very high degree of contamination. It is crucial to note that the DC values in the samples collected at the informal e-waste recycling sites were higher than the control site linking the contamination of the sites to the haphazard and informal e-waste recycling activities, using crude methods. The order of the overall degree of contamination at the sites was dismantling points at Ojota scrap market $>$ burning points at Ojota scrap market $>$ dismantling points at Alaba International Market $>$ burning points at Alaba International market > dumping points at Westminster $>$ repair points at Westminster $>$ dismantling points at Computer village, Ikeja $>$ dismantling points with traces of burning at Computer village, Ikeja. In all the informal e-waste recycling sites, dismantling points had the highest overall degree of contamination when compared to the other ewaste recycling activities such as burning, dumping and repairing going on at the sites. 
Table 6: Geo-accumulation Index (Igeo) of heavy metals in topsoil of informal e-waste recycling sites in Lagos

\begin{tabular}{|l|l|l|l|l|l|l|l|l|l|l|l|l|}
\hline $\begin{array}{l}\text { E-waste recycling } \\
\text { sites }\end{array}$ & $\mathbf{M n}$ & $\mathbf{F e}$ & $\mathbf{C r}$ & $\mathbf{C u}$ & $\mathbf{Z n}$ & $\mathbf{C o}$ & $\mathbf{C d}$ & $\mathbf{P b}$ & $\mathbf{N i}$ & $\mathbf{A s}$ & $\mathbf{A g}$ & $\mathbf{B a}$ \\
\hline $\begin{array}{l}\text { Alaba Intl' Market } \\
\text { (AIM) }\end{array}$ & & & & & & & & & & & & \\
\hline Burning points & -2.93 & -4.72 & -4.96 & 3.45 & 1.34 & - & 3.25 & 3.72 & -3.16 & -8.55 & -0.74 & -2.64 \\
\hline Dismantling points & -3.23 & -4.2 & -4.25 & 4.12 & 3.56 & - & - & 6.03 & -1.1 & - & -2.91 & -3.06 \\
\hline $\begin{array}{l}\text { Computer village, } \\
\text { Ikeja (ICV) }\end{array}$ & & & & & & & & & & & & \\
\hline Dismantling points & -2.75 & -3.73 & -4.15 & 0.23 & 0.76 & - & - & 2.13 & -5.01 & -7.97 & - & -8.07 \\
\hline $\begin{array}{l}\text { Dismantling points with } \\
\text { traces of burning }\end{array}$ & -2.94 & -3.91 & -4.6 & -0.79 & 0.9 & - & - & 1.02 & -4.3 & -7.55 & - & -9.87 \\
\hline $\begin{array}{l}\text { Westminster Market } \\
\text { (WMM) }\end{array}$ & & & & & & & & & & & & \\
\hline Repair points & -4.45 & -4.58 & -1.35 & -0.52 & 0.42 & - & - & 3.44 & -4.56 & - & - & -7.47 \\
\hline Dumping points & -3.54 & -4.15 & -2.84 & 2.28 & 3.14 & - & - & 3.5 & -0.93 & - & - & -2.86 \\
\hline $\begin{array}{l}\text { Ojota Scrap Market } \\
\text { (OJS) }\end{array}$ & & & & & & & & & & & & \\
\hline Dismantling points & -2.32 & -3.4 & -0.52 & 4.67 & 3.17 & - & - & 8.27 & -1.72 & - & - & -5.16 \\
\hline Burning points & -3.57 & -4.34 & -3.71 & 3.86 & 3.78 & - & 5.7 & 7.48 & -2.13 & -7.55 & - & -3.36 \\
\hline Control & -1.26 & -3.85 & -6.7 & -3.45 & -1.97 & - & - & -0.918 & -8.42 & - & - & - \\
\hline
\end{tabular}

Note: - mean concentrations were below the detection limit

Table 7: Contamination Factors (CF) and Degree of Contamination (DC) of heavy metals in topsoil of informal e-waste recycling sites in Lagos

\begin{tabular}{|c|c|c|c|c|c|c|c|c|c|c|c|c|c|}
\hline \multirow{2}{*}{$\begin{array}{l}\text { E-waste recycling } \\
\text { sites }\end{array}$} & \multicolumn{12}{|l|}{ CF } & \multirow[t]{2}{*}{ DC } \\
\hline & Mn & $\mathrm{Fe}$ & $\mathrm{Cr}$ & $\mathrm{Cu}$ & $\mathrm{Zn}$ & Co & $\mathrm{Cd}$ & $\mathrm{Pb}$ & $\mathrm{Ni}$ & As & Ag & $\mathrm{Ba}$ & \\
\hline $\begin{array}{l}\text { Alaba Intl' Market } \\
\text { (AIM) }\end{array}$ & & & & & & & & & & & & & \\
\hline Burning points & 0.20 & 0.06 & 0.05 & 16.4 & 3.80 & - & 14.3 & 19.8 & 0.17 & 0.004 & 0.9 & 0.24 & 55.9 \\
\hline Dismantling points & 0.16 & 0.08 & 0.08 & 26.14 & 17.7 & - & - & 97.8 & 0.70 & - & 0.2 & 0.18 & 143 \\
\hline \multicolumn{14}{|l|}{$\begin{array}{l}\text { Computer village, } \\
\text { Ikeja (ICV) }\end{array}$} \\
\hline Dismantling points & 0.22 & 0.11 & 0.08 & 1.76 & 2.54 & - & - & 6.56 & 0.05 & 0.01 & - & 0.01 & 11.3 \\
\hline $\begin{array}{l}\text { Dismantling points } \\
\text { with traces of burning }\end{array}$ & 0.20 & 0.10 & 0.06 & 0.87 & 2.80 & - & - & 3.04 & 0.08 & 0.01 & - & 0.002 & 7.16 \\
\hline \multicolumn{14}{|l|}{$\begin{array}{l}\text { Westminster Market } \\
\text { (WMM) }\end{array}$} \\
\hline Repair points & 0.09 & 0.06 & 0.59 & 1.04 & 2.01 & - & - & 16.3 & 0.06 & - & - & 0.01 & 20.1 \\
\hline Dumping points & 0.13 & 0.08 & 0.21 & 7.29 & 13.3 & 0.22 & - & 17 & 0.79 & - & - & 0.21 & 39.2 \\
\hline \multicolumn{14}{|l|}{$\begin{array}{l}\text { Ojota Scrap Market } \\
\text { (OJS) }\end{array}$} \\
\hline Dismantling points & 0.30 & 0.14 & 1.05 & 38.2 & 13.5 & - & - & 462 & 0.45 & - & - & 0.04 & 516 \\
\hline Burning points & 0.13 & 0.07 & 0.12 & 21.7 & 20.6 & - & 78 & 268 & 0.34 & 0.008 & - & 0.15 & 389 \\
\hline Control & 0.63 & 0.1 & 0.01 & 0.14 & 0.38 & & - & 0.79 & 0.004 & - & - & - & 2.05 \\
\hline
\end{tabular}

Note: - means concentration was below detection limit

The results of ecological risk factor (Eir) and (RI) are presented in Table 8 . The monomial potential ecological risk factor $\left(\mathrm{E}_{\mathrm{r}}^{\mathrm{i}}\right)$ was lower than 40 for $\mathrm{Cr}$, $\mathrm{Ni}$ and $\mathrm{Zn}$ across all the recycling sites indicating that these elements pose a low ecological risk.
However, $\mathrm{Cd}, \mathrm{Cu}$ and $\mathrm{Pb}$ had moderate to considerable risk at Alaba International Market while $\mathrm{Pb}$ had considerable risk at Westminster market; $\mathrm{Cu}$ and $\mathrm{Pb}$ had considerable to high risk at Ojota scrap market. However, the values of ecological risk index (RI) across all the informal e- 
waste recycling sites in Lagos ranged from 22.92,519. Ojota scrap market dismantling points and burning points, and dismantling points at Alaba International Market had ecological risk index above 400 . This indicated that the ecosystem is susceptible to a very high risk. The ecological risk index of informal e-waste recycling sites at Computer village, Ikeja and Westminster had considerable to moderate risks. The monomial potential ecological risk factor $\left(\mathrm{E}_{\mathrm{r}}^{\mathrm{i}}\right)$ and ecological risk index (RI) of all the informal e-waste recycling sites in Lagos were higher than what was obtained in the soil of the control site linking the ecological risk to the e-waste recycling activities at these sites.

The cancer risk of heavy metals in topsoil of informal e-waste recycling sites in Lagos ranged from 3.93-183 in both children and adults populations (Table 9). The average carcinogenic risk index of $\mathrm{As}, \mathrm{Pb}, \mathrm{Cd}, \mathrm{Ni}, \mathrm{Cu}, \mathrm{Cr}, \mathrm{Zn}, \mathrm{Co}$ and $\mathrm{Ba}$ across the informal e-waste recycling sites under the three exposure pathways was higher than the safe limit (0.0001), suggesting that the various ewaste recycling activities posed an unacceptable health risk to both children and adults around the sites. Chromium was the major contributor to the risk in all the sites except dismantling points at Alaba International Market and burning points at Ojota scrap market, where $\mathrm{Pb}$ was the dominant contributor to the risk. In addition, the exposure pathways were in the order: ingestion $>>$ inhalation $>$ dermal contact. Generally, children were more exposed to the risk than adults.

Hence, children around these sites were more susceptible to carcinogenic risk. Furthermore, the level of risk recorded at the control site was far lower than that of the recycling sites, revealing that the risk might be due to improper e-waste recycling at the sites. The hazardous emission of $\mathrm{Cd}$ and $\mathrm{Pb}$ through burning of e-waste ranged from 224-2,066 and 1,720-151,179, respectively in both children and adults populations around the informal e-waste recycling sites where e- waste burning is prevalent (Table 10). E-waste burning posed major health risk to the populations in all the selected sites since the values are greater than 1 , which can lead to chronic health impacts.

Table 8: Potential Ecological Risk Index of heavy metals in topsoil of informal e-waste recycling sites in Lagos

\begin{tabular}{|c|c|c|c|c|c|c|c|c|}
\hline \multirow{2}{*}{ E-waste recycling sites } & \multicolumn{7}{|l|}{ Eir } & \multirow[t]{2}{*}{ R.I } \\
\hline & $\mathrm{Cr}$ & $\mathrm{Cu}$ & $\mathrm{Zn}$ & $\mathrm{Cd}$ & $\mathrm{Pb}$ & $\mathrm{Ni}$ & As & \\
\hline \multicolumn{9}{|c|}{ Alaba Intl' Market (AIM) } \\
\hline Burning points & 0.1 & 81.8 & 3.8 & 142.67 & 99.1 & 0.84 & 0.04 & 328 \\
\hline Dismantling points & 0.16 & 131 & 17.68 & - & 489 & 3.49 & - & 641 \\
\hline \multicolumn{9}{|l|}{$\begin{array}{l}\text { Computer village, Ikeja } \\
\text { (ICV) }\end{array}$} \\
\hline Dismantling points & 0.17 & 8.79 & 2.54 & - & 32.8 & 0.23 & - & 44.5 \\
\hline $\begin{array}{l}\text { Dismantling points with } \\
\text { traces of burning }\end{array}$ & 0.12 & 4.34 & 2.8 & - & 15.2 & 0.38 & - & 22.9 \\
\hline \multicolumn{9}{|l|}{$\begin{array}{l}\text { Westminster Market } \\
\text { (WMM) }\end{array}$} \\
\hline Repair points & 1.18 & 5.22 & 2.01 & - & 81.3 & 0.32 & - & 90 \\
\hline Dumping points & 0.42 & 36.4 & 13.3 & - & 85 & 3.93 & - & 139 \\
\hline \multicolumn{9}{|c|}{ Ojota Scrap Market (OJS) } \\
\hline Dismantling points & 2.09 & 191 & 13.5 & - & 2311 & 2.27 & - & 2519 \\
\hline Burning points & 0.23 & 109 & 20.6 & - & 1338 & 1.71 & - & 1469 \\
\hline Control & 0.03 & 0.69 & 0.38 & - & 3.97 & 0.02 & - & 5.09 \\
\hline
\end{tabular}


Adeyi et al.: Distribution and Potential Risk of Metals and Metalloids in Soil of Informal E-waste Recycling Sites

Table 9: Cancer risk of heavy metals in topsoil of informal e-waste recycling sites in Lagos

\begin{tabular}{|c|c|c|c|c|c|c|c|c|c|c|}
\hline \multicolumn{11}{|c|}{ Alaba International Market (AIM) } \\
\hline \multicolumn{11}{|c|}{ Burning points } \\
\hline PATHWAY & $\mathrm{Pb}$ & $\mathrm{Ni}$ & $\mathrm{Zn}$ & $\mathrm{Cd}$ & $\mathrm{Cr}$ & $\mathrm{Cu}$ & As & $\mathrm{Ba}$ & Co & $\mathrm{HI}$ \\
\hline & \multicolumn{9}{|c|}{ Children } & \\
\hline Ingestion & 2.9529 & 0 & 0 & 0 & 5.2767 & 0 & 0.0329 & 0 & 0 & 8.2625 \\
\hline Dermal & 0 & 0 & 0 & 0 & 0 & 0 & 0.0042 & 0 & 0 & 0.0042 \\
\hline Inhalation & $1.12 \mathrm{E}-10$ & 0 & 0 & $1.14 \mathrm{E}-10$ & $3.30 \mathrm{E}-08$ & 0 & $2.53 \mathrm{E}-11$ & 0 & 0 & $3.35 \mathrm{E}-08$ \\
\hline \multirow[t]{2}{*}{$\mathrm{HI}$} & & & & & & & & & & 8.27 \\
\hline & \multicolumn{9}{|c|}{ Adults } & \\
\hline Ingestion & 1.5819 & 0 & 0 & 0 & 2.8268 & 0 & 0.0176 & 0 & 0 & 4.4263 \\
\hline Inhalation & $6.01 \mathrm{E}-11$ & 0 & 0 & 6.09E-11 & $1.78 \mathrm{E}-08$ & 0 & $1.35 \mathrm{E}-11$ & 0 & 0 & $1.8 \mathrm{E}-08$ \\
\hline Dermal & 0 & 0 & 0 & 0 & 0 & 0 & 0.0044 & 0 & 0 & 0.004362 \\
\hline \multirow[t]{2}{*}{$\mathrm{HI}$} & & & & & & & & & & 4.43 \\
\hline & & & & & & & & & & \\
\hline \multicolumn{11}{|c|}{ Dismantling points } \\
\hline & & & & & & & & & & \\
\hline & $\mathrm{Pb}$ & $\mathrm{Ni}$ & $\mathrm{Zn}$ & $\mathrm{Cd}$ & $\mathrm{Cr}$ & $\mathrm{Cu}$ & As & $\mathrm{Ba}$ & Co & $\mathrm{HI}$ \\
\hline & \multicolumn{9}{|c|}{ Children } & \\
\hline Ingestion & 14.57 & 0 & 0 & 0 & 8.66 & 0 & 0 & 0 & 0 & 23.23 \\
\hline Dermal & 0 & 0 & 0 & 0 & 0 & 0 & 0 & 0 & 0 & 0 \\
\hline Inhalation & $5.54 \mathrm{E}-10$ & 0 & 0 & 0 & $5.46 \mathrm{E}-08$ & 0 & 0 & 0 & 0 & $5.52 \mathrm{E}-08$ \\
\hline \multirow[t]{2}{*}{$\mathrm{HI}$} & & & & & & & & & & 23.2 \\
\hline & \multicolumn{9}{|c|}{ Adults } & \\
\hline Ingestion & 7.8 & 0 & 0 & 0 & 4.64 & 0 & 0 & 0 & 0 & 12.44 \\
\hline Dermal & 0 & 0 & 0 & 0 & 0 & 0 & 0 & 0 & 0 & 0 \\
\hline Inhalation & $2.97 \mathrm{E}-10$ & 0 & 0 & 0 & $2.93 \mathrm{E}-08$ & 0 & 0 & 0 & 0 & $2.96 \mathrm{E}-08$ \\
\hline $\mathrm{HI}$ & & & & & & & & & & 12.4 \\
\hline \multicolumn{11}{|c|}{ Computer village, Ikeja (ICV) } \\
\hline \multicolumn{11}{|c|}{ Dismantling points } \\
\hline & $\mathrm{Pb}$ & $\mathrm{Ni}$ & $\mathrm{Zn}$ & $\mathrm{Cd}$ & $\mathrm{Cr}$ & $\mathrm{Cu}$ & As & $\mathrm{Ba}$ & $\mathrm{Co}$ & $\mathrm{HI}$ \\
\hline \multicolumn{11}{|c|}{ Children } \\
\hline Ingestion & 0.98 & 0 & 0 & 0 & 9.26 & 0 & 0.05 & 0 & 0 & 10.3 \\
\hline Dermal & 0 & 0 & 0 & 0 & 0 & 0 & 0.01 & 0 & 0 & 0.01 \\
\hline Inhalation & $3.72 \mathrm{E}-11$ & 0 & 0 & 0 & $5.84 \mathrm{E}-08$ & 0 & 3.79E-11 & 0 & 0 & $5.85 \mathrm{E}-08$ \\
\hline $\mathrm{HI}$ & & & & & & & & & & 10.3 \\
\hline \multicolumn{11}{|c|}{ Adults } \\
\hline Ingestion & 0.52 & 0 & 0 & 0 & 4.96 & 0 & 0.03 & 0 & 0 & 5.51 \\
\hline Dermal & 0 & 0 & 0 & 0 & 0 & 0 & 0.01 & 0 & 0 & 0.01 \\
\hline Inhalation & $1.99 \mathrm{E}-11$ & 0 & 0 & 0 & $3.13 \mathrm{E}-08$ & 0 & $2.03 \mathrm{E}-11$ & 0 & 0 & $3.13 \mathrm{E}-08$ \\
\hline $\mathrm{HI}$ & & & & & & & & & & 5.52 \\
\hline \multicolumn{11}{|c|}{ Dismantling points with traces of burning } \\
\hline & $\mathrm{Pb}$ & $\mathrm{Ni}$ & $\mathrm{Zn}$ & $\mathrm{Cd}$ & $\mathrm{Cr}$ & $\mathrm{Cu}$ & As & $\mathrm{Ba}$ & Co & $\mathrm{HI}$ \\
\hline \multicolumn{11}{|c|}{ Children } \\
\hline Ingestion & 0.45 & 0 & 0 & 0 & 6.79 & 0 & 0.07 & 0 & 0 & 7.32 \\
\hline Dermal & 0 & 0 & 0 & 0 & 0 & 0 & 0.01 & 0 & 0 & 0.01 \\
\hline Inhalation & $1.72 \mathrm{E}-11$ & 0 & 0 & 0 & \begin{tabular}{|c|}
$4.29 \mathrm{E}-08$ \\
\end{tabular} & 0 & $5.06 \mathrm{E}-11$ & 0 & 0 & $4.29 \mathrm{E}-08$ \\
\hline $\mathrm{HI}$ & & & & & & & & & & 7.32 \\
\hline \multicolumn{11}{|c|}{ Adults } \\
\hline Ingestion & 0.24 & 0 & 0 & 0 & 3.64 & 0 & 0.04 & 0 & 0 & 3.92 \\
\hline Dermal & 0 & 0 & 0 & 0 & 0 & 0 & 0.01 & 0 & 0 & 0.01 \\
\hline Inhalation & $9.24 \mathrm{E}-12$ & 0 & 0 & 0 & $2.30 \mathrm{E}-08$ & 0 & 2.71E-11 & 0 & 0 & $2.30 \mathrm{E}-08$ \\
\hline $\mathrm{HI}$ & & & & & & & & & & 3.93 \\
\hline
\end{tabular}


Adeyi et al.: Distribution and Potential Risk of Metals and Metalloids in Soil of Informal E-waste Recycling Sites

Table 9 contd: Cancer risk of heavy metals in topsoil of informal e-waste recycling sites in Lagos

\begin{tabular}{|c|c|c|c|c|c|c|c|c|c|c|}
\hline \multicolumn{11}{|c|}{ Westminster Market (WMM) } \\
\hline \multicolumn{11}{|c|}{ Repair points } \\
\hline & $\mathrm{Pb}$ & $\mathrm{Ni}$ & $\mathrm{Zn}$ & $\mathrm{Cd}$ & $\mathrm{Cr}$ & $\mathrm{Cu}$ & As & $\mathrm{Ba}$ & Co & HI \\
\hline & \multicolumn{9}{|c|}{ Children } & \\
\hline Ingestion & 2.42 & 0 & 0 & 0 & 64.66 & 0 & 0 & 0 & 0 & 67.08 \\
\hline Dermal & 0 & 0 & 0 & 0 & 0 & 0 & 0 & 0 & 0 & 0 \\
\hline Inhalation & $9.21 \mathrm{E}-11$ & 0 & 0 & 0 & $4.08 \mathrm{E}-07$ & 0 & 0 & 0 & 0 & $4.08 \mathrm{E}-07$ \\
\hline \multirow[t]{2}{*}{$\mathrm{HI}$} & & & & & & & & & & 67.1 \\
\hline & \multicolumn{9}{|c|}{ Adults } & \\
\hline Ingestion & 1.3 & 0 & 0 & 0 & 34.64 & 0 & 0 & 0 & 0 & 35.94 \\
\hline Dermal & 0 & 0 & 0 & 0 & 0 & 0 & 0 & 0 & 0 & 0 \\
\hline Inhalation & $4.93 \mathrm{E}-11$ & 0 & 0 & 0 & $2.18 \mathrm{E}-07$ & 0 & 0 & 0 & 0 & $2.19 \mathrm{E}-07$ \\
\hline $\mathrm{HI}$ & & & & & & & & & & 35.9 \\
\hline \multicolumn{11}{|c|}{ Dumping points } \\
\hline & $\mathrm{Pb}$ & $\mathrm{Ni}$ & $\mathrm{Zn}$ & $\mathrm{Cd}$ & $\mathrm{Cr}$ & $\mathrm{Cu}$ & As & $\mathrm{Ba}$ & $\mathrm{Co}$ & $\mathrm{HI}$ \\
\hline & \multicolumn{9}{|c|}{ Children } & \\
\hline Ingestion & 2.53 & 0 & 0 & 0 & 23.01 & 0 & 0 & 0 & 0 & 25.55 \\
\hline Dermal & 0 & 0 & 0 & 0 & 0 & 0 & 0 & 0 & 0 & 0 \\
\hline Inhalation & $9.63 \mathrm{E}-11$ & 0 & 0 & 0 & $1.45 \mathrm{E}-07$ & 0 & 0 & 0 & $\begin{array}{l}\text { 4.19E- } \\
09\end{array}$ & $1.50 \mathrm{E}-07$ \\
\hline \multirow[t]{2}{*}{$\mathrm{HI}$} & & & & & & & & & & 25.6 \\
\hline & \multicolumn{9}{|c|}{ Adults } & \\
\hline Ingestion & 1.36 & 0 & 0 & 0 & 12.33 & 0 & 0 & 0 & 0 & 13.69 \\
\hline Dermal & 0 & 0 & 0 & 0 & 0 & 0 & 0 & 0 & 0 & 0 \\
\hline Inhalation & 5.16E-11 & 0 & 0 & 0 & 7.78E-08 & 0 & 0 & 0 & $\begin{array}{l}2.24 \mathrm{E}- \\
09\end{array}$ & $8.01 \mathrm{E}-08$ \\
\hline $\mathrm{HI}$ & & & & & & & & & & 13.7 \\
\hline \multicolumn{11}{|c|}{ Ojota Scrap Market (OJS) } \\
\hline \multicolumn{11}{|c|}{ Dismantling points } \\
\hline & $\mathrm{Pb}$ & $\mathrm{Ni}$ & $\mathrm{Zn}$ & $\mathrm{Cd}$ & $\mathrm{Cr}$ & $\mathrm{Cu}$ & As & $\mathrm{Ba}$ & Co & HI \\
\hline & \multicolumn{9}{|c|}{ Children } & \\
\hline Ingestion & 68.88 & 0 & 0 & 0 & 114.52 & 0 & 0 & 0 & 0 & 183.4 \\
\hline Dermal & 0 & 0 & 0 & 0 & 0 & 0 & 0 & 0 & 0 & 0 \\
\hline Inhalation & $2.62 \mathrm{E}-09$ & 0 & 0 & 0 & $7.22 \mathrm{E}-07$ & 0 & 0 & 0 & 0 & $7.25 \mathrm{E}-07$ \\
\hline \multirow[t]{2}{*}{$\mathrm{HI}$} & & & & & & & & & & 183 \\
\hline & \multicolumn{9}{|c|}{ Adults } & \\
\hline Ingestion & 36.9 & 0 & 0 & 0 & 61.35 & 0 & 0 & 0 & 0 & 98.25 \\
\hline Dermal & 0 & 0 & 0 & 0 & 0 & 0 & 0 & 0 & 0 & 0 \\
\hline Inhalation & 1.40E-09 & 0 & 0 & 0 & $3.87 \mathrm{E}-07$ & 0 & 0 & 0 & 0 & $3.88 \mathrm{E}-07$ \\
\hline $\mathrm{HI}$ & & & & & & & & & & 98.3 \\
\hline \multicolumn{11}{|c|}{ Burning points } \\
\hline & $\mathrm{Pb}$ & $\mathrm{Ni}$ & $\mathrm{Zn}$ & $\mathrm{Cd}$ & $\mathrm{Cr}$ & $\mathrm{Cu}$ & As & $\mathrm{Ba}$ & $\mathrm{Co}$ & $\mathrm{HI}$ \\
\hline & \multicolumn{9}{|c|}{ Children } & \\
\hline Ingestion & 39.87 & 0 & 0 & 0 & 12.6 & 0 & 0.07 & 0 & 0 & 52.54 \\
\hline Dermal & 0 & 0 & 0 & 0 & 0 & 0 & 0.01 & 0 & 0 & 0.01 \\
\hline Inhalation & 1.52E-09 & 0 & 0 & $6.21 \mathrm{E}-10$ & 7.95E-08 & 0 & $5.06 \mathrm{E}-11$ & 0 & 0 & $8.17 \mathrm{E}-08$ \\
\hline \multirow[t]{2}{*}{$\mathrm{HI}$} & & & & & & & & & & 52.6 \\
\hline & \multicolumn{9}{|c|}{ Adults } & \\
\hline Ingestion & 21.36 & 0 & 0 & 0 & 6.75 & 0 & 0.04 & 0 & 0 & 28.14 \\
\hline Dermal & 0 & 0 & 0 & 0 & 0 & 0 & 0.01 & 0 & 0 & 0.01 \\
\hline Inhalation & $8.12 \mathrm{E}-10$ & 0 & 0 & $3.33 \mathrm{E}-10$ & 4.26E-08 & 0 & $2.71 \mathrm{E}-11$ & 0 & 0 & $4.38 \mathrm{E}-08$ \\
\hline $\mathrm{HI}$ & & & & & & & & & & 28.2 \\
\hline
\end{tabular}


Table 9 contd: Cancer risk of heavy metals in topsoil of informal e-waste recycling sites in Lagos

\begin{tabular}{|c|c|c|c|c|c|c|c|c|c|c|}
\hline & \multicolumn{9}{|c|}{ Control } & \multirow[b]{2}{*}{$\mathrm{HI}$} \\
\hline & $\mathrm{Pb}$ & $\mathrm{Ni}$ & $\mathrm{Zn}$ & $\mathrm{Cd}$ & $\mathrm{Cr}$ & $\mathrm{Cu}$ & As & $\mathrm{Ba}$ & $\mathrm{Co}$ & \\
\hline & \multicolumn{9}{|c|}{ Children } & \\
\hline Ingestion & 0.12 & 0 & 0 & 0 & \begin{tabular}{|l|}
1.58 \\
\end{tabular} & 0 & 0 & 0 & 0 & 1.7 \\
\hline Dermal & 0 & 0 & 0 & 0 & 0 & 0 & 0 & 0 & 0 & 0 \\
\hline Inhalation & $4.50 \mathrm{E}-12$ & 0 & 0 & 0 & 9.95E-09 & 0 & 0 & 0 & 0 & $9.96 \mathrm{E}-09$ \\
\hline \multirow[t]{2}{*}{$\mathrm{HI}$} & & & & & & & & & & 1.7 \\
\hline & \multicolumn{9}{|c|}{ Adults } & \\
\hline Ingestion & 0.06 & 0 & 0 & 0 & 0.85 & 0 & 0 & 0 & 0 & 0.91 \\
\hline Dermal & 0 & 0 & 0 & 0 & 0 & 0 & 0 & 0 & 0 & 0 \\
\hline Inhalation & $2.41 \mathrm{E}-12$ & 0 & 0 & 0 & 5.33E-09 & 0 & 0 & 0 & 0 & $5.33 \mathrm{E}-09$ \\
\hline HI & & & & & & & & & & 0.91 \\
\hline
\end{tabular}

Table 10: Hazardous emission during burning of e-waste at informal e-waste recycling sites in Lagos

\begin{tabular}{|l|l|l|l|l|l|l|l|l|}
\hline Sites & \multicolumn{4}{|c|}{ Cd } & \multicolumn{4}{c|}{ Pb } \\
\hline & DI (mg/kg/day) & \multicolumn{2}{|c|}{ Hazardous emission } & \multicolumn{2}{l|}{ DI DI (mg/kg/day) } & Hazardous emission \\
\hline & Children & Adults & Children & Adults & Children & Adults & Children & Adults \\
\hline AIMB & 2.65 & 1.57 & 379 & 224 & 391.8 & 232.2 & 11,194 & 6,634 \\
\hline ICVDBS & - & - & - & - & 60.21 & 35.67 & 1,720 & 1,019 \\
\hline OJSB & 14.46 & 8.57 & 2,066 & 1,224 & 5291.25 & 3135.02 & 151,179 & 89,572 \\
\hline Control & - & - & - & - & 15.70 & 9.30 & 448 & 266 \\
\hline
\end{tabular}

\section{CONCLUSION}

Informal e- waste recycling activities released high level of heavy metals and metalloids into the environment (soil, water, and air). In most cases, metals and metalloids concentrations in the topsoil of the selected informal e-waste recycling sites in Lagos was in the order: dismantling $>$ burning $>$ dumping $>$ repair. E-waste dismantling and burning contributed significant metals and metalloids concentrations into the topsoil of the selected informal e-waste recycling sites in Lagos. This can have detrimental effects on the entire ecosystem and in particular human health via the different exposure pathways such as ingestion, dermal and inhalation routes. The different ewaste recycling activities posed an unacceptable human health risk to both children and adults. Hazardous emission of $\mathrm{Cd}$ and $\mathrm{Pb}$ during e-waste burning also showed cancer risk. Due to poverty and weak enforcement of regulations, different categories of people including the vulnerable groups such as children and women are exposed to different hazardous substances present in ewaste during crude and haphazard e-waste recycling in Lagos. Need for proper enlightenment of the people involved in crude e- waste recycling through understanding of the hazards of e-waste, the impacts of its disposal, and the dangers of informal or crude recycling is recommended.

\section{REFERENCES}

Adaramodu, A. A., Osuntogun, A. O., EhiEromosele, C. O. 2012. Heavy metal concentration of surface dust present in ewaste components: the Westminister electronic market, Lagos case study. Resources and Environment 2(2), 9-13.

Adelekan, B. A. and Abegunde, K. D. 2011. Heavy metals contamination of soil and groundwater at automobile mechanic villages in Ibadan, Nigeria. International Journal of the Physical Sciences 6(5), 10451058.

Adeyi, A. A. and Torto, N. 2014. Profiling heavy metal distribution and contamination in soil of old power generation station in Lagos, Nigeria. American Journal of Science and Technology.1(1), 1-10.

Adeyi, A. A., and Babalola, B. A. 2017. Lead and cadmium levels in residential soils of 
Lagos and Ibadan, Nigeria. J Health Pollut 7(13), 42-5.5.

Amfo-Otu, R., Bentum, J. K., and Omari S. 2013. Assessment of soil contamination through e-waste recycling activities in Tema community one. Environment and Pollution 2(2), 66-70.

Amos-Tautua, B. M. W., Onigbinde, A. O., and Ere, D. 2014. Assessment of some heavy metals and physicochemical properties in surface soils of municipal open waste dumpsite in Yenagoa, Nigeria. African Journal of Environmental Sciences and Technology 8(1), 41-47.

Araújo, M.G., Magrini, A., Mahler, C. F., and Bilitewski, B. 2012. A model for estimation of potential generation of waste electrical and electronic equipment in Brazil. Waste Manag. 32, 335-342.

Asante, K. A., Agusa, T., Biney, C. A., Agyekum, W. A., Bello, M., Otsuka, M., Itai, T., Takahashi, S., and Tanabe, S. 2012. Multitrace element levels and arsenic speciation in urine of e-waste recycling workers from Agbogbloshie, Accra in Ghana. Science of the Total Environment 424, 63-73.

Atiemo, S. M., Ofosu, F. G., Kwame Aboh, I. J. and Kuranchie-Mensah, H. 2012. Assessing the heavy metals contamination of surface dust from waste electrical and electronic equipment (e-waste) recycling site in Accra, Ghana. Research Journal of Environmental and Earth Sciences 4(5), 605-611.

Bakare, A. A., Adeyemi, A. O., Adeyemi, A., Alabi, O. A., and Osibanjo, O. 2012. Cytogenotoxic effects of electronic waste leachate in Allium cepa. Caryologia, 65(2), 94-100.

Baker, V. (2001). Endocrine disrupters - testing strategies to assess human hazard. Toxicology in Vitro. 15,413-419.

Bakare, A., Alabi, O., Gbadebo, A., Ogunsuyi, O., and Alimba, C. 2013. In vivo cytogenotoxicity and oxidative stress induced by electronic waste leachate and contaminated well water. Challenges. 4(2), 169-87.

Bost, M., Houdart, S., Oberli, M., Kalonji, E., Huneau., , J. F., Margaritis, I. 2016. Dietary copper and human health: Current evidence and unresolved issues. Journal of Trace Elements in Medicine and Biology 35, 107-115.

Bot, A. and Benites, J. 2005. The importance of soil organic matter. FAO Soil Bulletin. Food and Agriculture Organization of the United Nations, Rome. ISNB 92-5105366-9.

Brigden, K., Labunska, I., Santillo, D. and Allsopp, M. 2005. Recycling of electronic wastes in China and India: workplace and environmental contamination report. Greenpeace International.

Caravanos, J., Clark, E., Fuller, R., Lambertson, C. 2011. Assessing worker and environmental chemical exposure risks at an e-waste recycling and disposal site in Accra, Ghana. J Health Pollution 1, 1625.

Chai, M., Li, S. F., and Shen, X. 2014. Heavy Metal Contamination and Ecological Risk in Spartina Alterniflora Marsh in Intertidal Sediments of Bohai Bay, China. Marine Pollution Bulletin. 84(12), 115-124.

Chakraborty, P., Selvaraj, S., Nakamura, M., Prithiviraj, B., Cincinelli, A., Bang, J. J. 2018. PCBs and PCDD/Fs in soil from informal e-waste recycling sites and open dumpsites in India: Levels, congener profiles and health risk assessment. Science of the Total Environment 621, 930-938.

Chan, J. K. Y., Xing, G. H., Xu, Y., Liang, Y., Chen, L. X., Wu, S. C., Wong, C. K. C., Leung, C. K. M., and Wong, M. H. 2007. Body loadings and health risk assessment of polychlorinated dibenzo-p-dioxins and dibenzofurans at an intensive electronic waste recycling site in China. Environmental Science E Technology 41, 7668-7674.

Chen, A., Dietrich, K. N, Huo, X., and Ho, S. M. 2011. Developmental neurotoxicants in E-waste: An emerging health concern. Environmental Health Perspectives 119(4), 431-438.

Echegaray, F and Hansstein, F. V. 2017. Assessing the intention-behavior gap in electronic waste recycling: the case of Brazil. Journal 
of Cleaner Production 142, 180-190.

Eguchi, A., Nomiyama, K., Devanathan, G., Subramanian, A., Bulbule, K. A., Parthasarathy, P., Takahashi, S., and Tanabe, S. 2012. Different profiles of anthropogenic and naturally produced organohalogen compounds in serum from residents living near a coastal area and e-waste recycling workers in India. Environment International 47, 8-16.

European Commission. 1999. Communication from the Commission to the Council and the European Parliament. Community Strategy for Endocrine Disrupters a range of substances suspected of interfering with the hormone systems of humans and wildlife. COM (1999) 706 final. Brussels 17.12.1999.

Forstner, U., Ahlf, W., and Calmano, W. 1993. Sediment quality objectives and criteria development in Germany. Water Sci. Technol. 28, 307-316.

Fu, F., and Wang, Q. 2011. Removal of heavy metal ions from wastewaters: a review. $J$ Environ Manag. 92(3), 407-18.

Gray, C. W., McLaren, R. G., Roberts, A. H, and Condron, L. M. 1998. Sorption and desorption of cadmium from some New Zealand soils: Effect of $\mathrm{pH}$ and contact time. Aust. J. Soil Res. 36, 199-216.

Ha, N. N., Agusa, T., Ramu, K., Tu, N. P. C., Murata, S., Bulbule, K. A., Parthasaraty, P., Takahashi, S., Subramanian, A., and Tanabe, S. 2009. Contamination by trace elements at e-waste recycling sites in Bangalore, India. Chemosphere 76, 9-15.

Habes, G., and Nigem, Y. 2006. Assessing Mn, Fe, $\mathrm{Cu}, \mathrm{Zn}$, and $\mathrm{Cd}$ pollution in bottom sediments of Wad, Al-Arab Dam, Jordan. Chemosphere. 65(11), 2114-2121.

Haciyakupoglu, S., Esen, A. N., Erenturk, S., Okka, M., Genceli, M., Mercimek, M., et al. 2015. Determining distribution of heavy metal pollution in terms of ecological risk levels in soil of industrially intensive areas around Istanbul. Toxicol Environ Chem. 97(1), 62-75.

Hakanson, L. 1980. An ecological risk index for aquatic pollution control. A sedimentological approach. Water Res.
14(8), 975- 1001.

Huo, X., Peng, L., Xu, X., Zheng, L., Qiu, B., Qi, B., Qi, Z., Zhang, B., Han, D., and Piao, Z. 2007. Elevated blood lead levels of children in Guiyu an electronic waste recycling town in China. Environ Health Persp. 115(7), 1113-1117.

Huo, X., Li, Y., Xu, X. J., Wu, K. S., Liu, J. X., Chen, S. G., et al. 2008. Toxic heavy metal waste exposure and abnormal birth outcomes in an electronic waste recycling town of China. Toxicology Letters 180, S185.

Igharo, G. O., Anetor, J. L., Osibanjo, O. O., Osadolor, H.B., Aiyanyor, D. O. and David, O. M. (2015b). Status of prostate specific antigen and alpha fetoprotein in Nigerian E-waste workers: A cancer risk predictive study. J. Carcinogen. Mutagen 6(3), 224:1-5.

Igharo, G. O., Anetor, J. L., Osibanjo, O. O., Osadolor, H.B., Idomeh, F. A. Igiewe, W. O. and Kalikwu O. U. (2015a) Liver damage risk assessment study in workers occupationally exposed to e-waste in Benin City, South-South Nigeria. J. Chem. Health Risk 5(3), 155-166.

Igharo, G. O., Anetor, J. L., Osibanjo, O. O., Osadolor, H.B., David, O. M. and Agu, K. C. (2016). Oxidative stress and antioxidant status in Nigerian E-waste workers: a cancer risk predictive study. Brit. J. Med. Med.Res. 13(2), 1-11

Igharo, G. O., Anetor, J. L., Osibanjo, O. O., Osadolor, H.B., and Dike K. C. (2014). Toxic metal levels in Nigerian electronic waste workers indicate occupational metal toxicity associated with crude electronic waste management. Biokemistri 26, 99105.

Jaishankar, M., Tseten, T., Anbalagan, N., Mathew, B. B., Beeregowda, K. N. 2014. Toxicity, mechanism and health effects of some heavy metals. Interdiscip Toxicol. 7(2), 60-72.

Kabata-Pendias, A and Pendias, H. 2001. Trace Metals in Soils and Plants. 2nd edition. CRC Press, Boca Raton, Fla, USA.

Kaya, M. and Sözeri, A. 2009. A review of electronic waste (e-waste) recycling technologies "is e-waste an opportunity or 
232 Adeyi et al.: Distribution and Potential Risk of Metals and Metalloids in Soil of Informal E-waste Recycling Sites

treat"? 138th Annual Meeting of TMS, San Francisco, California, USA.

Kiddee, P., Naidu, R., and Wong, M. H. 2013. Electronic waste management approaches: An overview. Waste Management 33, 1237-1250.

Leung, A. O., Cai, Z. W., Wong, M. H. 2006. Environmental contamination from electronic waste recycling at Guiyu, southeast China. Journal of Material Cycles Waste Management 8(1), 21-33.

Leung, A. O. W., Duzgoren-Aydin, N. S., Cheung, K. C., and Wong. M. H. 2008. Heavy Metals Concentrations of Surface Dust from e-Waste Recycling and Its Human Health Implications in Southeast China. Environ. Sci. Technol. 42(7), 2674-2680.

Li, I., Duan, H., and Shi, P. 2011. Heavy metal contamination of surface soil in electronic waste dismantling area: site investigation and source-apportionment analysis. Waste Manag Res. 29, 727-738.

Liu, W. H., Zhao, J. Z., Ouyang, Z. Y., Solderland, L., Liu, G. H. 2005. Impacts of sewage irrigation on heavy metal distribution and contamination in Beijing, China. Environ. Int. 31,805-812.

Luo, C., Liu, C., Wang, Y., Liu, X., Li, F., Zhang, G., and Li, X. 2011. Heavy metal contamination in soils and vegetables near an e-waste processing site, south China. Journal of Hazardous Materials 186, 481-490.

Manhart, A., Osibanjo, O., Aderinto, A., and Prakash, S. 2011. Informal e-waste management in Lagos, Nigeria - socioeconomic impacts and feasibility of international recycling co-operations. Final report of component 3 of the UNEP SBC E-waste A frica Project.

Muller, G. 1969. Index of geoaccumulation in sediments of the Rhine River. J Geol. 2(3), 108-118.

Nukpezah, D., Okine, H. A. Oteng-Ababio, M., and Ofori, B. D. 2014. Electronic waste risk assessment and management in Ghana. Proceedings of the 28th Enviro Info 2014 Conference, Oldenburg, Germany. September 10-12, 2014.

Okorhi, O. J., Okereka, E. E., Akhimie, C. O.,
Enekwenchi, K. K. 2017. Frontiers and prospects for recycling waste electrical and electronic equipment (WEEE) in Nigeria. J. Appl. Sci. Environ. Manage. 21(7), 1382-1391.

Olafisoye, O. B., Adefioye, T., Osibote, O. A. 2013. Heavy metals contamination of water, soil, and plants around an electronic waste dumpsite. Pol J Environ Stud. 22(5), 1431-1439.

Oliver, D. P., Tiller, K. G., Alston, A. M., Cozens, G. D., and Merry, R. H. 1998. Effect of soil $\mathrm{pH}$ and applied cadmium on cadmium concentration in wheat grain. Aust. J. Soil Res. 36, 571-583.

Onwughara, N. I., Nnorom, I. C., Kanno, O. C., and Chukwuma, R. C. 2010. Disposal methods and heavy metals released from certain electrical and electronic equipment wastes in Nigeria: adoption of environmental sound recycling system. International Journal of Environmental Science and Development 1(4), 290-297.

Pérez-Belis, V., Bovea, M. D., and Ibáñez-Forés, V. 2015. An in-depth literature review of the waste electrical and electronic equipment context: Trends and evolution. Waste Management $\mathcal{E}$ Research 33(1), 3-29.

Perkins, D. N., Drisse, M. B., Nxele, T. and Sly, P. D. 2014. E-Waste: A Global Hazard. Annals of Global Health 80, 286-295.

Plum, L. M., Rink, L., and Haase, H. 2010. The essential toxin: impact of zinc on human health. Int J Environ Res Public Health 7(4), 1342-1365.

Puckett, J., and Smith, T. 2002. Exporting harm the high-tech trashing of Asia. In: Coalition, S.V.T. (Ed.).

Rahimzadeh, M. R., Rahimzadeh, M. R., Kazemi, S., Moghadamnia, A. 2017. Cadmium toxicity and treatment: An update. Caspian JIntern Med. 8(3), 135-145.

Robinson, B. H. 2009. Review E-waste: An assessment of global production and environmental impacts. Science of the Total Environment 408, 183-191.

Sheikh, I. A., Tayubi, I. A., Ahmad, E., Ganaie, M. A., Bajouh, O. S., Al Basri, S. F., Abdulkarim, I. M., and Beg, M. A. 2017. Computational insights into the molecular 
Adeyi et al.: Distribution and Potential Risk of Metals and Metalloids in Soil of Informal E-waste Recycling Sites

interactions of environmental xenoestrogens 4-tert-octylphenol, 4nonylphenol, bisphenol A (BPA), and BPA metabolite, 4-methyl-2, 4-bis (4hydroxyphenyl) pent-1-ene (MBP) with human sex hormone-binding globulin. Ecotoxicol.Environ. Saf.15, 284-291.

Singh, R., Gautam, N., Mishra, A., and Gupta, R. 2011. Heavy metals and living systems: An overview. Indian J Pharmacol. 43(3), 246-253.

Society for Toxicology (SOT). 2013. Global Health and Environmental Impacts of EWaste Recycling. AAAS Annual Meeting, Boston. Retrieved on the $23^{\text {rd }}$ of January 2019 at http://aaas.confex.com/aaas /2013/webprogram/session5983.html

Song, Q., and Li, J. 2014. Environmental effects of heavy metals derived from the e-waste recycling activities in China: A systematic review. Waste Management 34(12), 2587 2594.

Steiner, S. 2004. Risk Assessment of E-waste burning in Delhi, India. Diploma Thesis. Umweltwissenschaften Eidgenössische Technische Hochschule Zürich.

Subburaman, C. 2012. E-waste hazardous: impacts on environment and human health. International Journal of Pharmacentical \& Biological Archives 3(2), 363-367.

Thatcher, R. W., Lester, M. L., Mcalaster, R., and Horst, R. 1982. Effects of Low Levels of Cadmium and Lead on Cognitive Functioning in Children. Archives of Environmental Health: An International Journal 37(3), 159-166.

Tsydenova, O., and Bengtsson, M. 2011. Chemical hazards associated with treatment of waste electrical and electronic equipment.
Waste Management 31(1), 45-58.

Udosen, E. D., Udoessien, E. I. and Ibok, U. J. 1990. Evaluation of some metals in the Industrial wastes from a paint industry and their environment pollution implications. Nig. J. Technol. Res. 2, 7177.

USEPA (2007). Method 3051A, Microwave assisted acid digestion of sediments, sludges, soils and oils. Washington, DC.

Walkley, A., and Black, I. A. 1934. Methods of soil analysis. Soil Sci.37:29-38.

Wang, T., Fu, J. J., Wang, Y. W., Liao, C. Y., Tao, Y. Q., and Jiang, G. B. 2009. Use of scalp hair as indicator of human exposure to heavy metals in an electronic waste recycling area. Environmental Pollution 157, 2445-2451.

Williams, E., Kahhat, R., Allenby, B., Kavazajian, E., Kim, J., and Xu, M. 2008. Environmental, social and economic implications of global reuse and recycling of personal computers. Environmental Science E Technology 42, 6446-6454.

Wardhana, W., and Datau, E. A. 2014. Metal fume fever among galvanized welders. Acta Med Indones. 46(3), 256-262.

Zhao, G.,Wang, Z., Dong, M. H., Rao, K., Luo, J., Wang, D., Zha, J., Huang, S., Xu, Y., and Ma, M. 2008. PBBs, PBDEs, and PCBs levels in hair of residents around e-waste disassembly sites in Zhejiang Province, China, and their potential sources. Sci TotalEnviron. 397, 46-57.

Zheng, L. K., Wu, K. S., Li, Y., Qi, Z. L, Han, D., Zhang, B., et al. 2008. Blood lead and cadmium levels and relevant factors among children from an e-waste recycling town in China. Environmental Research 108, 15-20. 